\title{
A PRESENÇA FENÍ́CIA EM LISBOA: NOVOS VESTÍGIOS DESCOBERTOS NO ALTO DA COlina do CAstelo de SÃo Jorge
}

Phoenician Presence in Lisbon: New Evidences from the Castelo de São Jorge's Hill

ELISA DE SOUSA ㅁ, SANDRA GUERRA

Universidade de Lisboa, Facultade de Letras; Uniarq - Centro de Arqueologia da Universidade de Lisboa. e.sousa@campus.ul, smsguerra70@gmail.com

\section{Resumo:}

Neste trabalho apresentam-se os primeiros contextos bem caracterizados da fase inicial da ocupação da Idade do Ferro na Colina do Castelo de São Jorge, em Lisboa (Portugal). Escavações arqueológicas realizadas nesta área urbana permitiram, pela primeira vez, detectar uma sequência clara da ocupação da fase Orientalizante da cidade, que se inicia durante o século VII e se prolonga até ao século V a.C. Os vestígios estratigráficos, arquitectónicos e o espólio recolhido, que integra sobretudo ânforas, produções cinzentas, de engobe vermelho, vasos de fabrico manual e cerâmica comum e pintada, são analisados com detalhe, revelando o profundo carácter orientalizante das populações que se instalaram, durante a $1^{a}$ metade do $1^{\circ}$ milénio a.C., na antiga Olisipo.

Palavras chave: Ocidente Atlântico; Tejo; Lisboa; fenícios; cultura material.

\section{Abstract:}

This paper presents the first accurate contexts related to the initial phase of the Iron Age occupation in the Castelo de São Jorge's Hill, in Lisbon (Portugal). Archaeological excavations carried out in this urban area allowed, for the first time, to identify a clear sequence of the city's Orientalizing occupation, which began during the 7th century and continues until the 5th century BC. Architectural and stratigraphic elements, as well as the associated artifacts, which include amphorae, gray and red slip wares, handmade vessels and common and painted pottery, are analyzed in detail, revealing the profound Orientalizing background of the populations that settled in ancient Olisipo during the 1 st half of the 1st millennium $B C$.

Key words: Western Atlantic, Tagus, Lisbon, Phoenician, material culture. 


\section{INTRODUÇÃO}

Elementos associáveis a uma importante presença de matriz orientalizante têm sido sistematicamente descobertos em vários pontos da Colina do Castelo de São Jorge, em Lisboa. Trata-se de uma elevação bem destacada na paisagem, que oferece boas condições de defensabilidade e, sobretudo, um extenso domínio visual sobre o território envolvente, em particular em direcção ao estuário do Tejo, factores que seguramente justificaram a sua eleição como um dos principais núcleos de ocupação desta região durante a Idade do Ferro (figs. 1 e 2).

As escavações que têm sido feitas ao longo desta Colina, sempre no quadro da arqueologia urbana, têm proporcionado dados muito importantes para a caracterização do

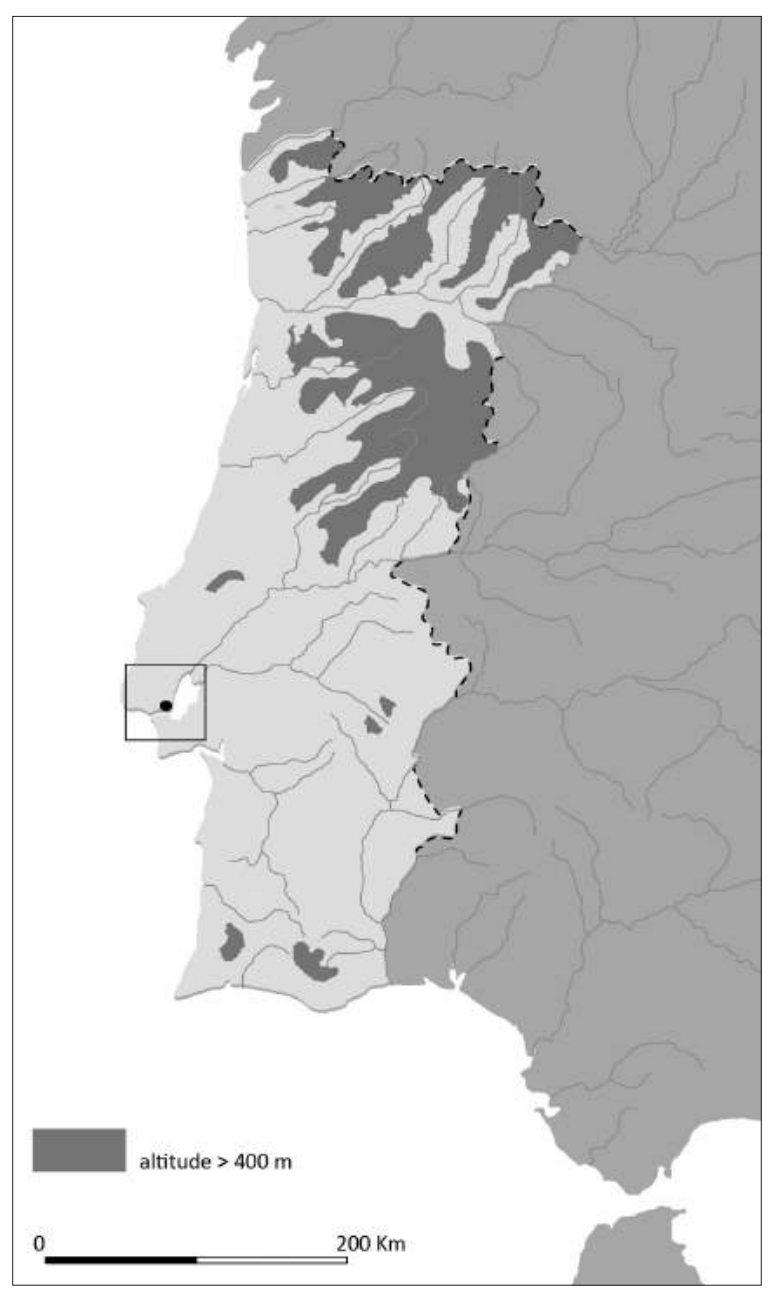

Fig. 1: Localização de Lisboa no actual território português. espaço durante o período sidérico, revelando a grande importância de vestígios arquitectónicos e, sobretudo, da cultura material, que se prendem indiscutivelmente com uma forte presença de agentes fenício-ocidentais no centro da fachada atlântica do território português (para uma síntese recente ver Sousa 2015, 2016a) (fig. 3).

No entanto, dados que pudessem permitir uma melhor caracterização destes elementos na área mais elevada da Colina permaneceram, durante mais de duas décadas, por publicar, apesar de se terem realizado extensas intervenções nesse espaço, em concreto no interior do Castelo de São Jorge.

Em 2015, a remodelação de um edifício localizado no Largo de Santa Cruz do Castelo (n. $\left.{ }^{\circ} 7\right)$, obrigou à escavação de várias áreas no seu interior que possibilitaram recolher dados que permitem agora colmatar esta lacuna no estudo das ocupações antigas de Lisboa e, acima de tudo, compreender de forma mais pormenorizada o profundo impacto que a chegada de populações fenício-ocidentais provocou na região. Naturalmente, as condicionantes inerentes à prática da arqueologia urbana limitaram fortemente uma leitura mais abrangente destes vestígios, que se encontram segmentados quer pelas construções recentes, quer pela forte dinâmica ocupacional que se verificou no topo da Colina durante os últimos dois mil anos.

O trabalho que é agora apresentado incide no estudo da ocupação da Idade do Ferro de um dos sectores que foram aqui intervencionados (Logradouro - Casa das Máquinas / Caixa de Drenagem), e que abrangeu uma área de cerca de $10 \mathrm{~m}^{2}$. O facto de se ter podido escavar a área em profundidade, até ao substrato geológico, é um elemento que deve ser valorizado, considerando que se trata de uma situação infelizmente rara no quadro da arqueologia urbana da cidade. Por outro lado, e apesar das reduzidas dimensões

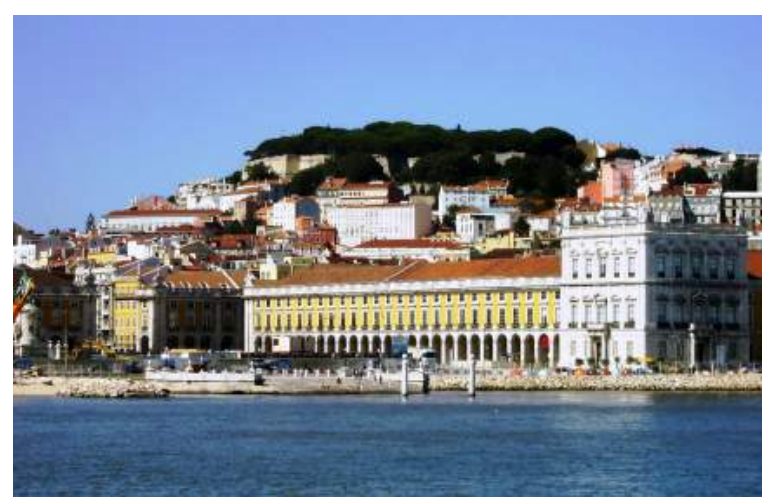

Fig. 2: A colina do Castelo de São Jorge vista do Tejo. 


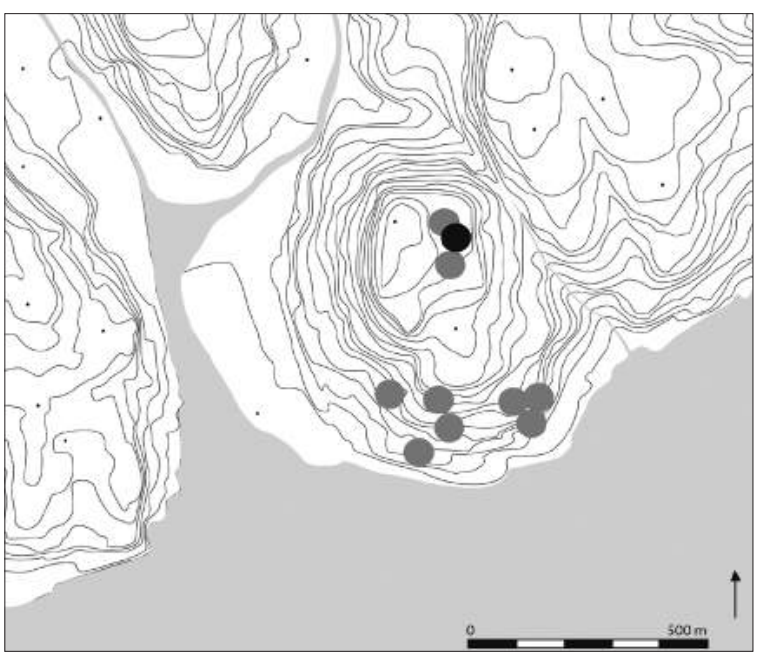

Fig. 3: Localização das escavações realizadas na Colina do Castelo que revelaram vestígios de ocupação durante o período orientalizante; a negro, o Largo de Santa Cruz do Castelo (7) (segundo Pimenta 2005, modificado).

do espaço intervencionado, foi possível, pela primeira vez, recolher dados que permitem uma caracterização mais segura e pormenorizada da sequência da fase inicial da ocupação da Idade do Ferro da antiga Lisboa, factor que ganha especial importância quando temos em consideração a quase total ausência de informações devidamente publicadas sobre este período no topo da Colina do Castelo de São Jorge.

A sequência estratigráfica identificada nesta área permitiu reconhecer cinco fases no quadro da ocupação sidérica, que se podem enquadrar, cronologicamente, entre o século VII e o século V a.C. Trata-se de fases que denunciam dinâmicas de construção, utilização e reestruturação do espaço intervencionado, que, contudo, nem sempre adquirem uma expressão cronológica evidente.

\section{OS DADOS ESTRATIGRÁFICOS}

A fase mais antiga detectada nesta intervenção (fase 1) integra uma série de realidades estratigráficas depositadas directamente sobre o substrato rochoso, formado por calcários e arenitos. Algumas destas camadas correspondem a depósitos sedimentares que teriam como função colmatar depressões do substrato geológico (U.E. [11=22], [33], [35]) e servir de preparação para a construção do nível de ocupação primário. Este último (U.E. [34]), que infelizmente se conservou apenas numa área muito reduzida, seria composto por um pavimento de terra

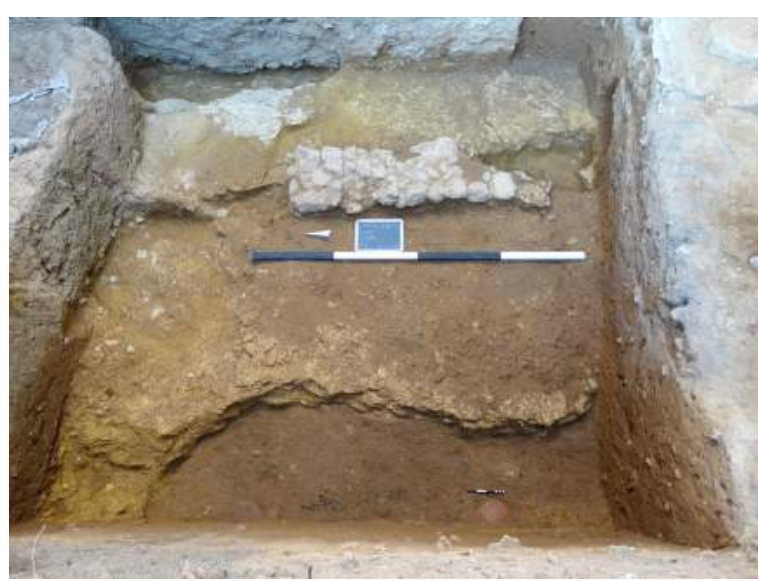

Fig. 4: Fase final dos trabalhos, sendo visível a estrutura pétrea.

batida e pequenos seixos, e estaria provavelmente associado à estrutura localizada no centro da área intervencionada. Esta, de orientação $\mathrm{N}$ - S , é construída em alvenaria simples, sendo os blocos pétreos calcários ligados por um sedimento argiloso (fig. 4). É ainda importante assinalar que um dos níveis de preparação (U.E. [35]), localizado directamente sob o pavimento (U.E. [34]), cobria uma inumação infantil (U.E. [36]), tendo esta sido depositada sobre o substrato rochoso, sem qualquer espólio associado. Um estudo mais detalhado sobre esta evidência, assim como de uma outra detectada em outro sector, encontra-se actualmente em preparação. Contudo, deve assinalar-se que a existência de inumações infantis associadas a fases de construções ou reformulações de novos espaços edificados não é inédita no quadro da ocupação sidérica portuguesa, tendo sido documentada no Castelo de Castro Marim, ainda que durante uma fase mais tardia (século V a.C.) (Arruda 2005: 77-78; Arruda et al. 2007: 472), podendo relacionar-se com práticas rituais fundacionais com fortes conotações simbólicas, ainda que seja, de momento, difícil rastrear a sua origem específica e integração cultural.

A segunda fase de ocupação parece consubstanciar-se num momento de remodelação deste mesmo espaço. Com efeito, a estrutura referida anteriormente permanece em utilização, estando agora associada a níveis de cronologia relativa mais recente. Neste segundo momento, a Oeste deste muro, foi detectado um novo nível interpretado como preparação de um outro pavimento (U.E. [25]), que infelizmente não se conservou, mas que estaria associado a uma área de combustão localizada na área norte (U.E. [28]), composta por uma placa de argila bastante queimada, e em torno da qual se detectaram algumas concentrações 


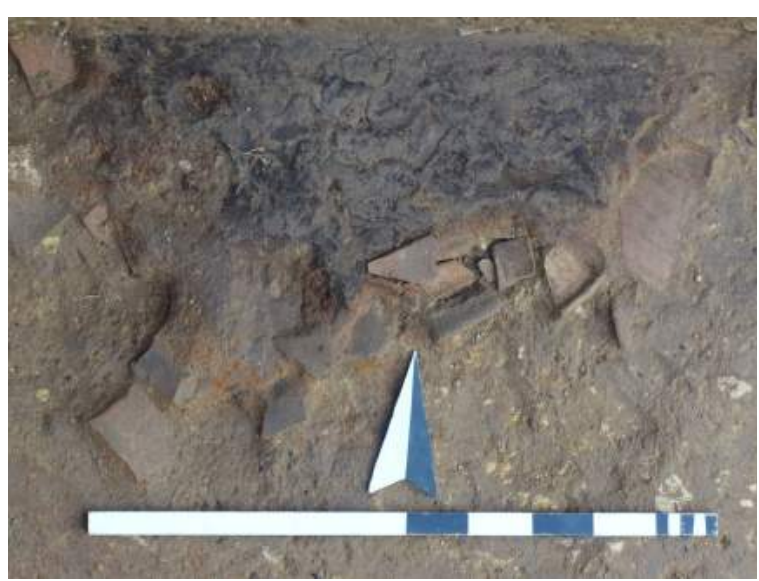

Fig. 5: Área de combustão [28], [29].

de fragmentos cerâmicos (U.E. [29]) (fig. 5), que poderiam ter tido uma função refratária capaz de resistir a altas temperaturas e manter o calor. Junto ao corte $\mathrm{O}$ foi identificada uma outra área com nódulos de argilas amareladas e carvões (U.E. [27]) e, sob esta, uma outra camada semelhante, mas com cinzas (U.E. [30]), que se parecem associar também a este momento de ocupação, podendo

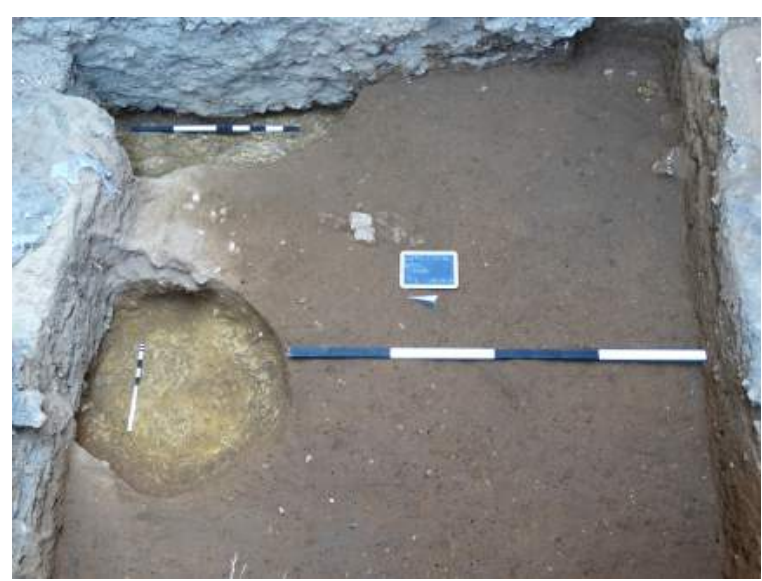

Fig. 6: Estrutura negativa [20].

relacionar-se com outras áreas de combustão. A esta fase pertence ainda um nível com maior concentração de elementos pétreos (U.E. $[10=26]$ ), localizado a este da estrutura, que poderá corresponder a um derrube. Infelizmente, a proximidade desta realidade aos limites da área intervencionada dificultam uma caracterização e interpretação mais pormenorizada.

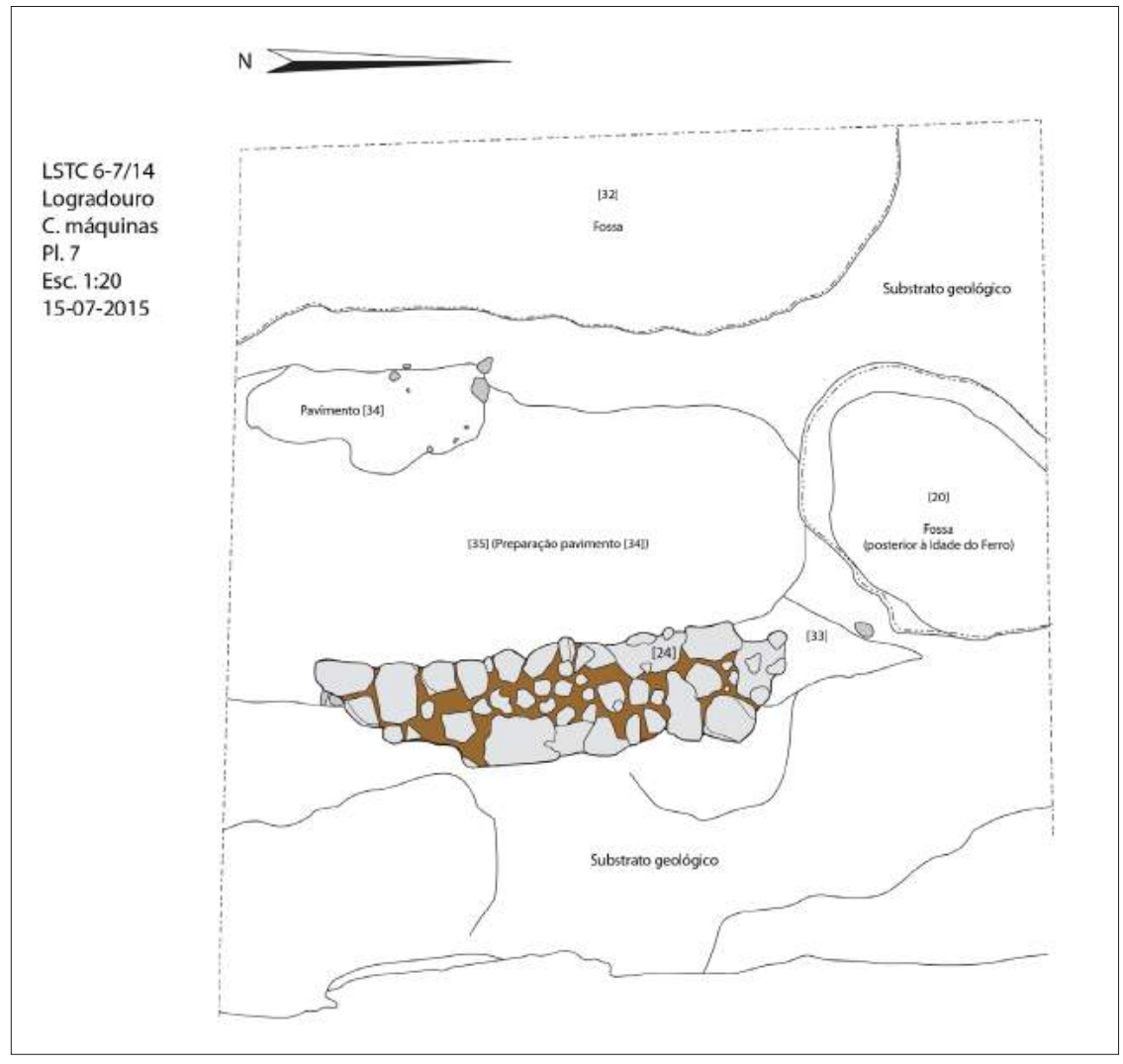

Fig. 7: Planta da fase 1 da área escavada no Logradouro - Casa das Máquinas / Caixa de Drenagem. 


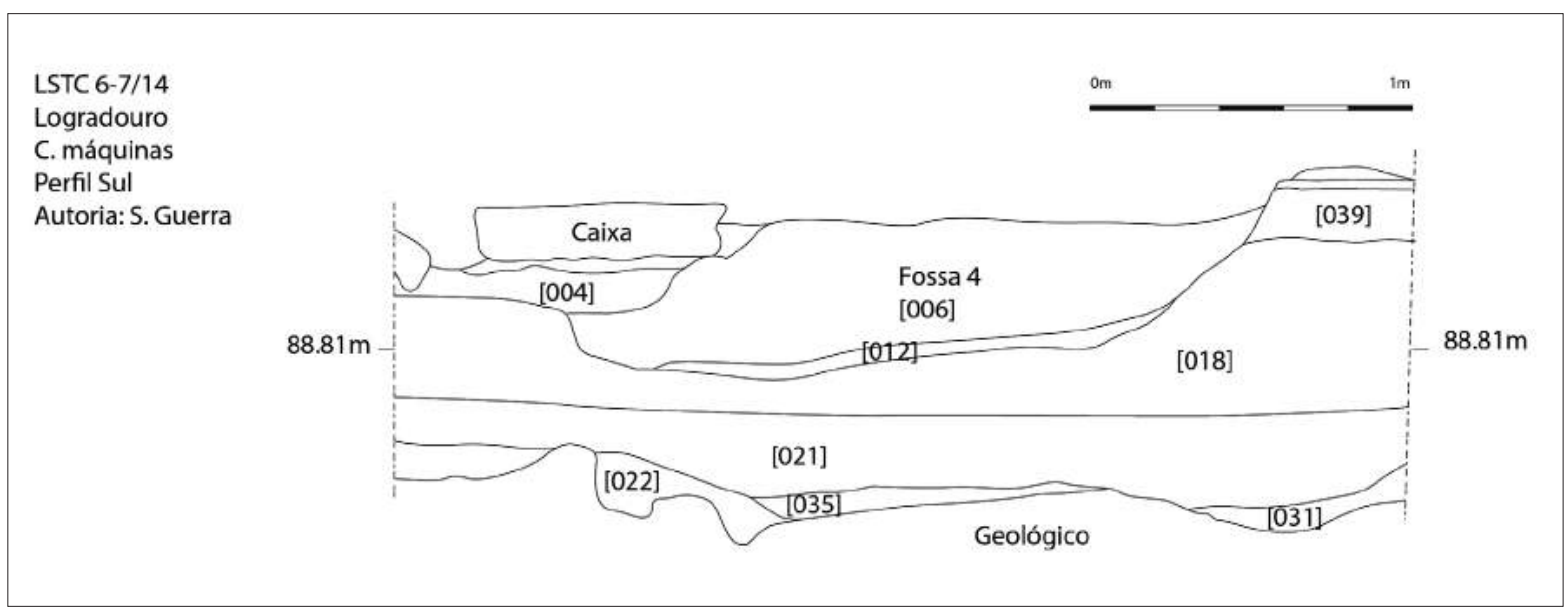

Fig. 8: Perfil sul da área escavada no Logradouro - Casa das Máquinas / Caixa de Drenagem.

A terceira fase de ocupação da Idade do Ferro é definida pela deposição de uma camada relativamente espessa (U.E. [9=21]), com abundantes nódulos de carvão e inclusões de argila de tonalidades variadas, entre o amarelo e o avermelhado. Este estrato cobria a quase totalidade da área escavada neste sector. É difícil determinar se corresponderia a um estrato de aterro e/ou a um nível de ocupação relacionado com estruturas localizadas fora da área intervencionada.

A mesma questão é aplicável ao estrato sucessivo (U.E. [8=18]), de tonalidade castanha-alaranjada, com pedras de pequena e média dimensão, nódulos de carvão e de argila amarela e alaranjada, que também se estendia pela quase totalidade da zona escavada. Apesar de não ser possível distinguir claramente, em termos arquitectónicos, este momento do anterior, certas alterações verificadas no quadro da cultura material condicionaram a individualização deste momento (fase 4).

A última fase de ocupação sidérica deste espaço integra apenas duas realidades estratigráficas. Uma delas é uma fossa (U.E. [20]), que corta o nível anterior (U.E. [18]) e que estava preenchida por um sedimento com múltiplos nódulos de argila de colorações variáveis, carvões, cinzas e pedras de pequena e média dimensão (U.E. [19]) (fig. 6). $\mathrm{Na}$ zona $\mathrm{O}$ da área intervencionada registou-se ainda uma outra camada (U.E. [15]), composta por um sedimento argiloso alaranjado, com pedras de pequena e média dimensão, carvões e inclusões de argilas amarelas, verdes e alaranjadas. É possível que estes níveis se associassem a uma fase construtiva mais recente que terá sido, contudo, muito afectada pelas construções e ocupações de época posterior.

\section{A CULTURA MATERIAL}

Os materiais recolhidos nos níveis conservados da Idade do Ferro deste sector (Logradouro - Casa das Máquinas / Caixa de Drenagem) totalizam 688 fragmentos inventariáveis (508 NMI), distribuíveis pelas seguintes categorias: ânforas (36 fragmentos: $27 \mathrm{NMI}$ ), cerâmica de engobe vermelho (40 fragmentos: $31 \mathrm{NMI}$ ), cerâmica cinzenta (204 fragmentos: 157 NMI), cerâmica comum ou pintada (381 fragmentos: $274 \mathrm{NMI}$ ), cerâmica manual (22 fragmentos: $14 \mathrm{NMI}$ ), uma possível importação do Mediterrâneo Oriental (um fragmento: $1 \mathrm{NMI}$ ) e outros objectos (três fragmentos: $3 \mathrm{NMI}$ ). Uma única peça (um fragmento: $1 \mathrm{NMI}$ ) pertence a um artefacto metálico, de bronze (fig. 10).

Com raríssimas excepções, que serão devidamente assinaladas, a esmagadora maioria dos materiais cerâmicos enquadra-se nos grupos de fabrico que são considerados serem de origem local, sendo praticamente idênticos aos detectados, em fases algo posteriores, na Rua dos Correeiros, também em Lisboa (Sousa 2014):

- Os recipientes anfóricos caracterizam-se por apresentarem pastas não calcárias, compactas, de fractura regular, com grau de depuração algo variável, sendo identificáveis inclusões de moscovites, biotites, calcites, quartzos e plagióclases. As suas tonalidades oscilam entre o castanho e o alaranjado, ou, mais raramente, o acinzentado. Correspondem ao grupo I estabelecido para o conjunto anfórico da Rua dos Correeiros (Sousa 2014: 91).

- No grupo da cerâmica de engobe vermelho, os fabricos identificados são também homogéneos, com pastas 

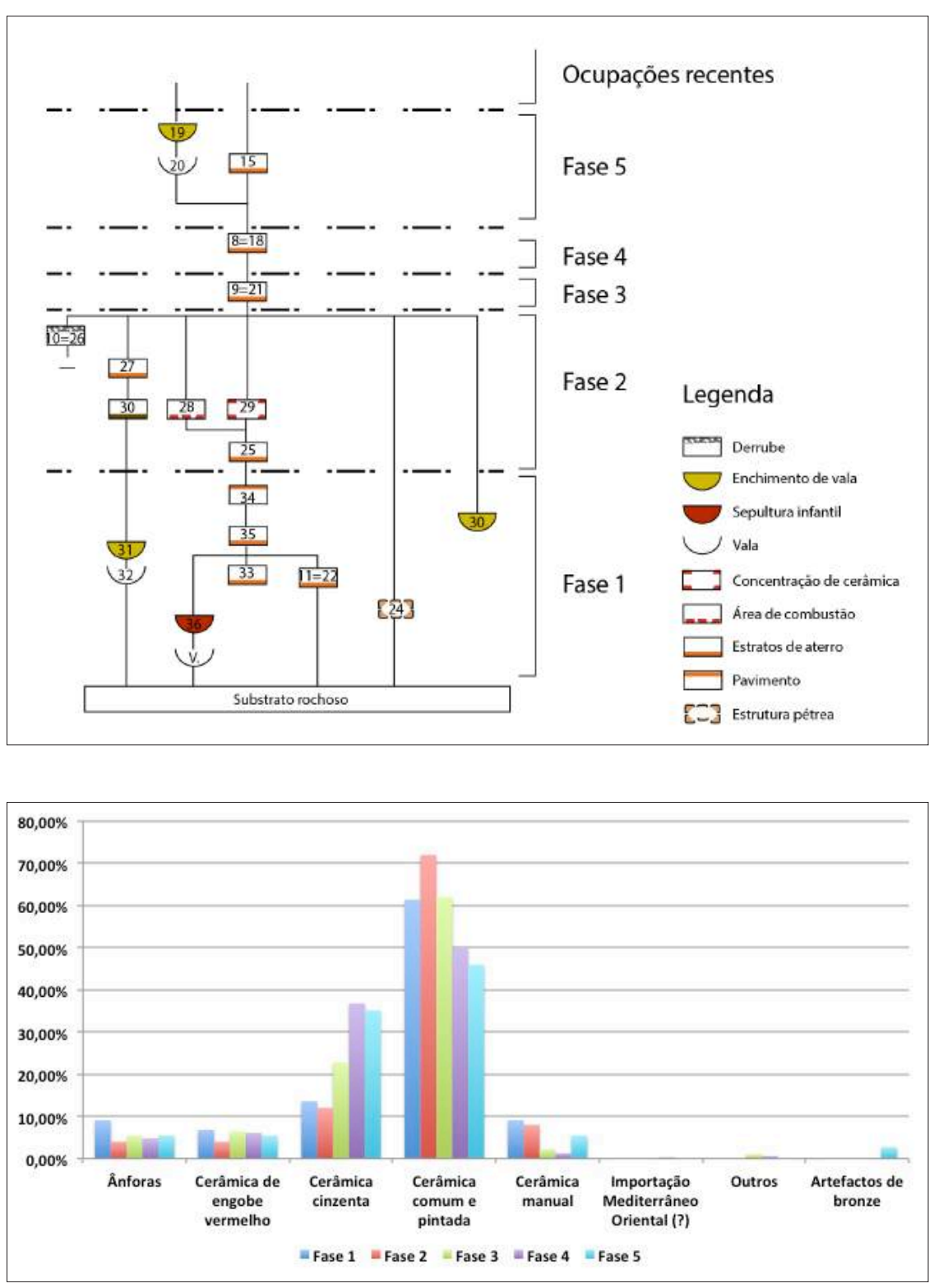

Fig. 9: Matriz estratigráfica da ocupação da Idade do Ferro da área do Logradouro - Casa das Máquinas / Caixa de Drenagem.
Fig. 10: Distribuição das categorias de artefactos de acordo com as fases de ocupação (base NMI). não calcárias, compactas, de fractura regular e bem depuradas, sendo identificáveis partículas de moscovites, biotites, calcites, quartzos, piroxenas e alguns nódulos ferruginosos. A sua tonalidade é castanha-alaranjada. Os engobes são, por sua vez, relativamente espessos e de tom avermelhado. Correspondem ao grupo I estabelecido para o conjunto de cerâmica de engobe vermelho da Rua dos Correeiros (Sousa 2014: 115).

- Os fragmentos de cerâmica cinzenta são, por sua vez, divisíveis em dois subgrupos. Embora em ambos estejam incluídas pastas não calcárias, compactas e bem depuradas, com inclusões de moscovite, calcites, nódulos ferruginosos e quartzos, num dos casos o seu núcleo é de tom avermelhado (Grupo II da Rua dos Correeiros - Sousa 2014: 131) sendo, no outro, cinzento (Grupo III da Rua dos Correeiros - Sousa 2014: 131). Em ambos, as superfícies são sempre cuidadosamente polidas.

- A cerâmica comum ou com decoração pintada é também facilmente divisível em dois fabricos diferenciados. O primeiro engloba pastas não calcárias, compactas, de fractura regular e mediamente depuradas, com 
inclusões de calcites, quartzos, moscovites, biotites e plagióclase, sendo de tons alaranjados ou acastanhados (Grupo I estabelecido para a cerâmica comum da Rua dos Correeiros - Sousa 2014: 145). O segundo caracteriza-se também por pastas não calcárias, mas que são pouco compactas e pouco depuradas, sendo identificáveis partículas de dimensões variáveis de quartzos, calcites, moscovites, nódulos ferruginosos, biotites e anfibolites. A sua pasta é alaranjada, apresentando um acabamento pouco cuidado, com superfícies rugosas (Grupo III estabelecido para a cerâmica comum da Rua dos Correeiros - Sousa 2014: 145). Trata-se de um fabrico específico que é aparentemente destinado unicamente a vasos usados para cozinhar que apresentam, com muita frequência, as suas superfícies externas queimadas, sendo provável que as suas características tenham sido intencionalmente planeadas para suportar temperaturas mais elevadas. Neste último grupo não se regista qualquer exemplar com decoração pintada, sendo o único motivo identificado a aplicação de linhas incisas.

- Por último, a cerâmica manual agrupa exemplares com pastas pouco compactas e mal depuradas, com frequentes inclusões de moscovites, calcites, quartzos e biotites, sendo as suas tonalidades castanhas escuras. O tratamento das suas superfícies é, contudo, variável, existindo casos em que estas são cuidadosamente polidas, apresentando nestes casos pastas mais bem depuradas, em outros alisadas, e, em outros ainda, rugosas.

\section{FASE 1}

Os materiais recolhidos nos níveis da fase 1 totalizam 61 fragmentos classificáveis (44 NMI), que, com a excepção de apenas um fragmento de ânfora, se enquadram no âmbito das produções locais. A maioria do conjunto é composta por vasos de cerâmica comum a torno, que podem por vezes exibir decoração pintada (40 fragmentos: $27 \mathrm{NMI}$ ), seguindo-se a cerâmica cinzenta (sete fragmentos: $6 \mathrm{NMI}$ ), as produções manuais (sete fragmentos: 4 NMI), ânforas (quatro fragmentos: 4 NMI) e cerâmicas de engobe vermelho (tres fragmentos: 3 NMI) (figs. 11 e 12).

No conjunto anfórico, um único exemplar (1 NMI; n. ${ }^{\circ}$ 1) apresenta características de fabrico que permitem considerar tratar-se de uma importação meridional, muito provavelmente oriunda da costa malaguenha, exibindo semelhanças com alguns exemplares integrados por $\mathrm{J}$. Ramon no seu tipo 10.1.1.1. (1995: 461; n. $\left.{ }^{\circ} 1\right)$, ainda que algo atípicos. Os restantes (3 NMI; n. 2 e 3) parecem corresponder a produções locais do tipo 1 do estuário do Tejo, uma forma que parece de certa forma reproduzir os modelos meridionais 10.1.1.1 e 10.1.2.1 (Sousa e Pimenta 2014), caracterizando-se por um bordo curto e ligeiramente evertido, estando bem assinalada a sua separação do resto do corpo, e exibindo pinturas na zona externa e também na área superior interna, de tons avermelhados e acastanhados. Estas produções locais exibem já, contudo, características particulares, especialmente ao nível do diâmetro do bordo, que é consideravelmente mais amplo do que os protótipos meridionais, uma peculiaridade constante no repertório centro-atlântico (Sousa e Pimenta 2014).

A cerâmica de engobe vermelho está representada por apenas três exemplares (3 NMI), que correspondem a bordos de pratos de perfil simples e praticamente indiferenciáveis do resto da parede (n. 4 e 5), ainda que apenas um dos casos apresente um perfil mais bem conservado. Um destes fragmentos (n. ${ }^{\circ}$ ) apresenta, na área interna, linhas pintadas a negro que se sobrepõem ao engobe vermelho, uma particularidade que surge com alguma frequência nas produções da área de Lisboa (Sousa 2016a; 2017). A horizontalidade das paredes e a escassa sinalização do lábio na superfície interna recorda, de certa forma, os tipos P2(c) e P3(c) de Rufete, que surgem, na área de Huelva, em contextos balizados entre meados do século VII a.C.e meados do século VI a.C. (Rufete 1988-1989), ou o tipo I.B de Montemolín, datável da primeira metade do século VI a.C. (Mancebo 1991-1992). Contudo, o facto de se tratar de uma produção local obriga a ter alguma cautela na extrapolação directa dos parâmetros cronológicos estabelecidos para a zona meridional peninsular, podendo estas características morfológicas corresponderem a uma tendência que se tenha desenvolvido no quadro das produções do estuário do Tejo em momentos mais precoces, uma possibilidade que terá, contudo, de ser confirmada em estudos futuros. Neste âmbito, cabe talvez recordar que, em La Fonteta, pratos de engobe vermelho com bordos bastante aplanados surgem também em momentos relativamente antigos, concretamente durante a $1^{\text {a }}$ metade do século VII a.C. (Rouillard et al. 2007).

As produções cinzentas também se encontram representadas neste conjunto (6 NMI), sendo, contudo, o seu repertório reduzido. Os exemplares mais bem conservados (4 NMI; n. ${ }^{\circ} 6$ e 7) correspondem a taças de bordo evertido e corpo tendencialmente ovalado, uma morfologia frequente em Lisboa e que parece ser especialmente 
Elisa de Sousa, Sandra Guerra

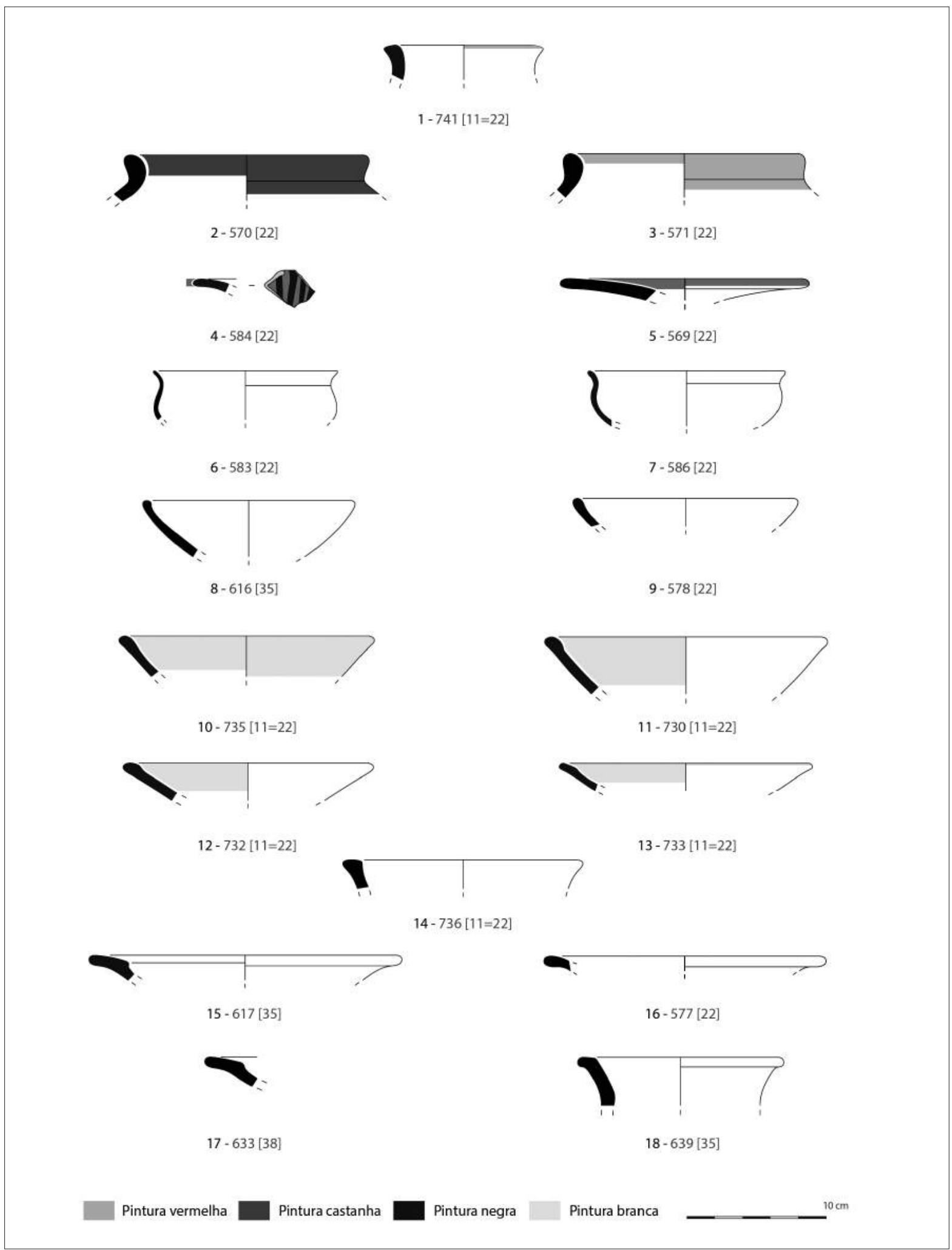

Fig. 11: Materiais da fase 1. 


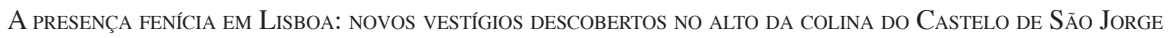

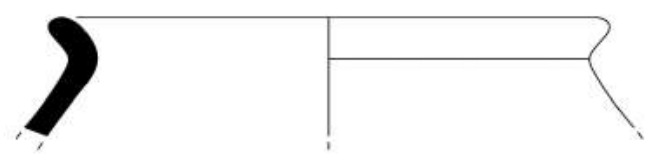

$19-560[22]$
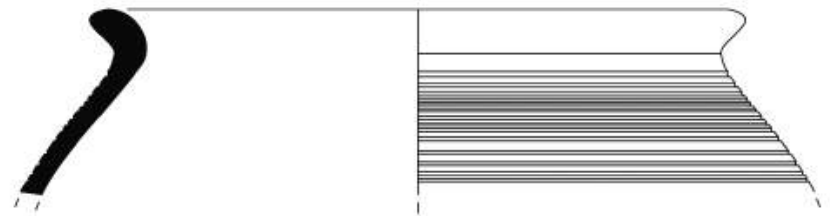

$20-559[22]$

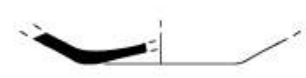

$21-566[22]$

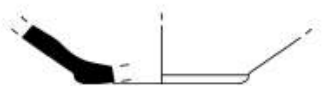

$23-613$ [35]

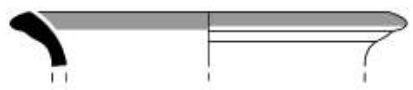

$25-568[22]$

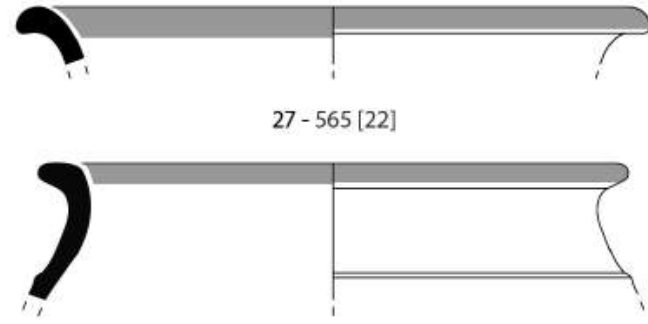

$28-561$ [22]

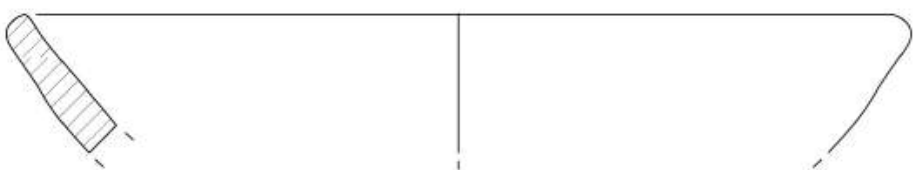

$31-562[22]$

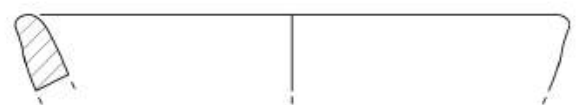

$32-748[11=22]$

Pintura vermelha

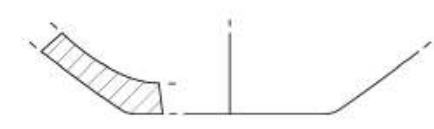

$33-612$ [35]

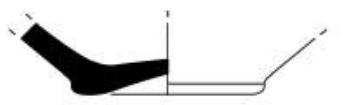

$22-575$ [22]

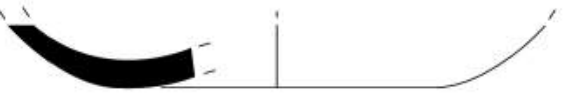

$24-611$ [35]

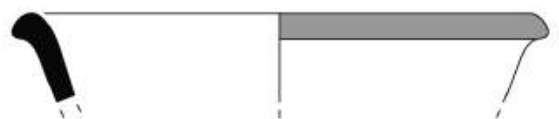

$26-563$ [22]

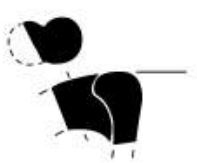

$29-564$ [22]

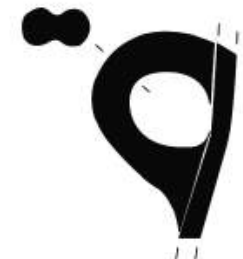

$30-742[11=22]$

$D_{1}^{1}-2 D$

34 - 576 [22]

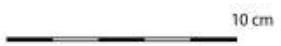

Fig. 12: Materiais da fase 1. 
apta para o consumo de líquidos (Sousa 2016a). A única outra forma documentada (2 NMI) corresponde a tigelas de perfil hemisférico e bordo ligeiramente espessado no interior, semelhante ao tipo 1Aa da Rua dos Correeiros (Sousa 2014). Deste conjunto faz ainda parte um fragmento de fundo, de perfil convexo, provavelmente correspondente às taças anteriormente descritas.

O conjunto das restantes cerâmicas produzidas a torno, com ou sem pintura, é o mais representativo entre os materiais desta fase, oferecendo um elenco morfológico mais variado, sendo apenas dois os exemplares inclassificáveis (2 NMI). Com a excepção de dois fragmentos (n. ${ }^{\circ}$ 19 e 20), todos são integráveis no grupo I estabelecido para a Rua dos Correeiros. Entre as formas abertas, identificaram-se tigelas de perfil hemisférico, com bordo ligeiramente espessado (7 NMI; n. 8 a 11), ou mais aplanado (4 NMI; n. ${ }^{\circ} 12$ e 13), apresentando um outro exemplar paredes mais verticais e um bordo quase horizontal (1 NMI; n. . 14). Os pratos surgem também no conjunto, exibindo lábios bem marcados na área interna (4 NMI; n. 15 a 17), que recordam as morfologias mais típicas da cerâmica de engobe vermelho. Todas estas peças apresentam, com frequência, acabamentos cuidados, sendo as suas superfícies polidas ou então recobertas com engobes ou aguadas de tons esbranquiçados, características que sugerem a sua utilização no serviço de mesa, e que estão bem documentadas em outros locais da cidade (Sousa 2016a). No conjunto de formas fechadas é possível distinguir dois grandes grupos. Um deles corresponde a vasos nos quais é frequentemente aplicada decoração pintada a vermelho na superfície externa e, por vezes, também na interna, junto ao bordo. A grande maioria (5 NMI; n. 26 a 29) corresponde a pithoi, de perfil algo variável, podendo o colo ser mais rectilíneo (n. $\left.{ }^{\circ} 26\right)$ ou arredondado (n. $\left.{ }^{\circ} 28\right)$. Um destes exemplares conserva ainda a asa parcialmente conservada, de secção bífida, que arranca do bordo (n. $\left.{ }^{\circ} 29\right)$, sendo um outro fragmento, de idêntico perfil (n. ${ }^{\circ} 30$ ), seguramente pertencente também a esta forma. Um outro exemplar (1 NMI; n. $\left.{ }^{\circ} 25\right)$, com diâmetro mais reduzido, poderá corresponder, genericamente, a uma outra morfologia, provavelmente também destinada ao armazenamento. Deve ainda destacar-se a presença de um bordo evertido, com diâmetro algo reduzido e colo alto, que poderá corresponder a algum tipo de jarro ou a uma urna Cruz del Negro (1 NMI; $n$. 18). O outro grupo de vasos fechados é composto por peças de fabrico bem diferenciado (Grupo III da Rua dos Correeiros), com pastas mais grosseiras, apresentando invariavelmente marcas de exposição ao fogo na zona exterior, elemento que indicia a sua utilização recorrente no processo de confecção de alimentos (2 NMI; n. ${ }^{\circ}$ 19 e 20). Correspondem a panelas de perfil em S, exibindo um dos exemplares (n. $\left.{ }^{\circ} 20\right)$ uma série de caneluras incisas na área externa. Trata-se de uma forma bastante frequente no $\mathrm{S}$ do território peninsular, como se verifica no Cerro del Villar (Aubet et al. 1999), Castillo de Doña Blanca (Ruiz 1993; Ruiz e Pérez Pérez 1995), Camposoto (forma DIVa2; Ramon et al. 2007) e em Huelva (Rufete 2002), entre outros. No grupo da cerâmica comum e pintada incluem-se ainda doze fragmentos de fundo, de perfil convexo (oito fragmentos; $n$. $^{\circ} 21$ e 22), aplanado (dois fragmentos; n. ${ }^{\circ} 23$ ) e côncavo (dois fragmentos; $n .^{\circ} 24$ ), podendo estes últimos corresponder à base dos vasos de tipo pithoi anteriormente referidos.

No conjunto desta primeira fase de ocupação documentaram-se ainda alguns fragmentos de produção manual. Os únicos que permitiram uma classificação morfológica correspondem a tigelas de perfil hemisférico, de dimensões variáveis (3 NMI; n. 31 e 32), com superfícies alisadas ou grosseiras. É ainda importante referir a presença de um fragmento de parede (1 NMI; n. $\left.{ }^{\circ} 34\right)$ que conserva, no seu exterior, decoração de "ornatos brunidos" aplicada numa superfície cuidadosamente polida, e que poderá ter pertencido a uma taça carenada. Os restantes fragmentos de produção manual correspondem a bases (dois fragmentos; n. ${ }^{\circ} 33$ ), de perfil plano ou convexo, com superfícies alisadas, e a uma parede com decoração mamilar.

As características do espólio recolhido nesta primeira fase de ocupação permitem propor uma cronologia centrada no século VII a.C. para a formação dos níveis arqueológicos correspondentes, sendo semelhantes a outros contextos mais ou menos coevos documentados na área de Lisboa (para uma síntese recente ver Sousa 2016a). A presença da panela com incisões na área superior poderia, contudo, sugerir uma baliza mais tardia dentro desta centúria, em torno ao seu último quartel, considerando os paralelos existentes na área meridional do território peninsular (para uma síntese recente, ver Torres et al. 2014: 72). Deve, contudo, referir-se que o exemplar de Lisboa exibe uma multiplicidade de linhas incisas que se diferencia de outros exemplares mais tardios, recolhidos também na área da Colina do Castelo (Sousa 2014: 169), e mais semelhantes aos da área andaluza, não tendo sido possível identificar uma correspondência exacta para as 
especificidades da peça recolhida na fase 1 , pelo que é difícil propor uma cronologia segura, não se podendo colocar totalmente de parte a possibilidade de se tratar de um exemplar um pouco mais antigo. Contudo, apenas a publicação de novos dados devidamente contextualizados poderá permitir confirmar ou refutar esta possibilidade. Ao confirmar-se esta última hipótese, seria, por conseguinte, necessário rever a proposta cronológica desta fase 1 para momentos mais tardios (a partir do último quartel do século VII a.C.) . No entanto, as características dos restantes materiais associados, como é o caso do fragmento de cerâmica manual decorada com ornatos brunidos externos, a ânfora importada e as morfologias das taças de cerâmica cinzenta, que se distanciam claramente dos protótipos típicos do século VI a.C., são outros elementos que poderão suportar uma datação centrada no século VII a.C. para esta fase 1.

\section{FASE 2}

Os níveis incluídos na segunda fase de ocupação da Idade do Ferro proporcionaram 39 fragmentos classificáveis (25 NMI). Tal como ocorre na fase anterior, o conjunto é formado maioritariamente pela cerâmica comum ou pintada a torno (28 fragmentos: $18 \mathrm{NMI}$ ), seguindo-se a cerâmica cinzenta (cinco fragmentos: $3 \mathrm{NMI}$ ), as produções manuais (tres fragmentos: 2 NMI) e as ânforas (dois fragmentos: $1 \mathrm{NMI}$ ). A cerâmica de engobe vermelho está representada por apenas um exemplar, que corresponde a um fragmento de carena, com pintura vermelha na superfície interna, que infelizmente não permitiu uma classificação morfológica específica (um fragmento: 1 NMI) (fig. 13).

Entre os fragmentos pertencentes a ânforas contabilizou-se apenas um bordo ligeiramente evertido e assinalado (1 NMI; n. ${ }^{\circ} 35$ ), com pintura vermelha na área superior, integrável no tipo 1 do estuário do Tejo (Sousa e Pimenta 2014), e uma asa de secção circular (n. ${ }^{\circ} 36$ ), que provavelmente pertence a esta mesma peça.

Na cerâmica cinzenta verificam-se as mesmas morfologias que na fase precedente: taças de corpo ovalado e bordo evertido (2 NMI; $n .^{\circ} 37$ ) e tigelas de perfil hemisférico e bordo ligeiramente espessado do tipo $1 \mathrm{Aa}$ da Rua dos Correeiros (1 NMI). Deste conjunto faz ainda parte um fundo de perfil convexo e um pequeno apendículo, de secção triangular e perfurado (n. $\left.{ }^{\circ} 38\right)$, que poderá corresponder a um alabastrón do tipo E1 de Medellín, datável do último quartel do século VII a.C. (Lorrio
2008: 712-713), ainda que esta classificação seja feita com muitas reservas, atendendo às escassas dimensões do fragmento.

$\mathrm{Na}$ cerâmica comum e pintada a torno, as formas abertas são predominantes, em particular as tigelas de perfil simples e bordo ligeiramente engrossado (8 NMI; n. 39 a 42) e outras que se distinguem pela presença de um bordo mais aplanado e assinalado exteriormente (7 NMI; n. 43 a 46). Ambas as morfologias exibem, regra geral, as superfícies bem polidas. As formas fechadas são mais raras, englobando, tal como na fase anterior, um vaso de bordo evertido, de diâmetro reduzido e colo alto, que poderá corresponder a um jarro ou a uma urna tipo Cruz del Negro (1 NMI; n. ${ }^{\circ} 47$ ). Um outro exemplar, de fabrico mais grosseiro e com marcas de exposição ao fogo na superfície externa, conservando ainda o arranque de uma asa na área do colo, corresponde, uma vez mais, a uma panela (1 NMI; n. $\left.{ }^{\circ} 48\right)$ do Grupo de Fabrico III. A este conjunto soma-se ainda um fragmento de bordo que não permitiu uma classificação específica (1 NMI), uma asa de secção circular, duas paredes com decoração incisa no interior (n. ${ }^{\circ} 51$ e 52 ), duas pintadas no exterior, em retícula (n. $\left.{ }^{\circ} 49\right)$ ou com bandas paralelas (n..$^{\circ}$ ), conservando este último exemplar ainda o arranque de uma asa. Os cinco fragmentos de fundo recolhidos nesta fase são maioritariamente de perfil convexo (n. 53 e 54), sendo apenas um de perfil côncavo (n. $\left.{ }^{\circ} 55\right)$, podendo este pertencer, pelas suas características de fabrico (Grupo III), à panela anteriormente descrita.

As produções manuais são escassas, incluindo apenas um fragmento com superfícies polidas (1 NMI; n. ${ }^{\circ} 56$ ), que corresponderá, com grande probabilidade, a uma taça carenada. Os restantes fragmentos pertencem a fundos de perfil ligeiramente convexo (1 NMI; n. ${ }^{\circ} 57$ e 58), com superfícies polidas ou alisadas.

Este repertório artefactual é muito semelhante ao registado na fase anterior, podendo admitir-se, também neste caso, a uma cronologia centrada no século VII a.C., particularmente no seu último quartel.

\section{FASE 3}

Os níveis desta terceira fase proporcionaram 131 fragmentos classificáveis (92 NMI). A categoria mais bem representada segue sendo a cerâmica comum ou pintada (85 fragmentos: $57 \mathrm{NMI}$ ), seguindo-se a cerâmica cinzenta (30 fragmentos: 21 NMI), a cerâmica de engobe 
Elisa de Sousa, Sandra Guerra

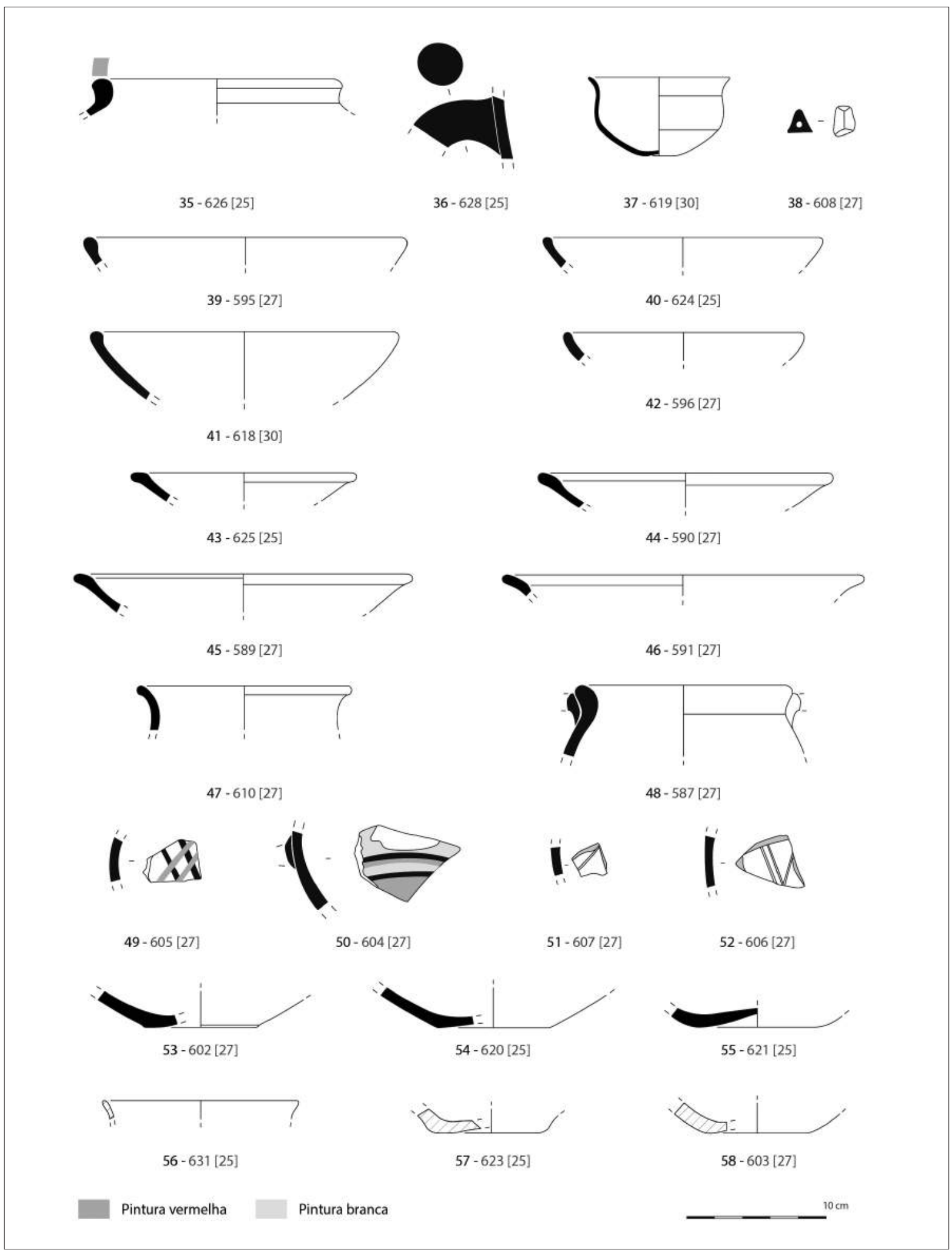

Fig. 13: Materiais da fase 2. 
vermelho (seis fragmentos: $6 \mathrm{NMI}$ ), os contentores anfóricos (cinco fragmentos: $5 \mathrm{NMI}$ ) e, por último, a cerâmica manual (quatro fragmentos: $2 \mathrm{NMI}$ ). Contabilizou-se ainda um fragmento afeiçoado em forma de placa circular, feito a partir de uma parede pintada com engobe vermelho (1 NMI) (fig. 14 a 16).

Entre o conjunto anfórico recolhido identificaram-se formas facilmente enquadráveis no tipo 1 do estuário do Tejo (3 NMI; n. ${ }^{\circ} 59$ a 61), com características morfológicas muito semelhantes às das fases anteriores, devendo assinalar-se a presença de uma pequena moldura na área externa de um destes recipientes (n. $\left.{ }^{\circ} 61\right)$. No entanto, outros dois fragmentos (2 NMI; n. 62 e 63 ), ainda que passíveis de serem integrados nesse mesmo tipo 1 , exibem bordos já mais evertidos, um elemento que poderá corresponder a uma evolução das formas anteriores, e que irá culminar no aparecimento, algumas décadas mais tarde, do tipo 3 do estuário do Tejo (Sousa e Pimenta 2014). A maioria destes exemplares apresenta revestimentos na superfície externa, em concreto a aplicação de engobes brancos e, em dois casos, de pintura vermelha.

Os vasos cobertos com engobe vermelho pertencem sobretudo a pratos de bordo aplanado (4 NMI; n. ${ }^{\circ} 64$ e $65)$, podendo um outro exemplar corresponder a algum tipo de tigela, aparentemente pouco profunda, exibindo bandas negras aplicadas sobre a pintura vermelha (1 NMI; n. ${ }^{\circ}$ 66). O restante fragmento exibe um diâmetro reduzido e bordo evertido, sendo provavelmente pertencente a um pequeno vaso (1 NMI; n. ${ }^{\circ}$ 67).

A cerâmica cinzenta está bem representada nesta fase, sendo a forma mais recorrente a taça de pequenas dimensões e de corpo ovalado (7 NMI), idêntica à das fases anteriores (n. ${ }^{\circ} 74$ e 76 ), ainda que em alguns casos se verifique uma tendência mais globular no corpo (n. ${ }^{\circ}$ 73, 75 e 77), mantendo, contudo, o bordo evertido. Outros exemplares são mais difíceis de classificar devido ao seu estado de fragmentação, ainda que pareçam corresponder também a morfologias de pequena dimensão (3 NMI; n. 78 a 80). Também expressiva é a tigela de perfil simples e bordo ligeiramente engrossado (6 NMI; n. ${ }^{\circ} 68$ a 70), seguindo-se os pratos de bordo aplanado (2 NMI; n. 71 e 72), por vezes bem diferenciado (n. $\left.{ }^{\circ} 72\right)$. Deste conjunto fazem ainda parte alguns bordos de forma indeterminada (3 NMI) e nove fragmentos de fundo, três dos quais de perfil aplanado (n. $\left.{ }^{\circ} 82\right)$ e seis convexos (n. ${ }^{\circ} 81$ e 83 ), um dos quais com uma incisão em forma de $\mathrm{X}$ no fundo externo.
A cerâmica comum e pintada é a categoria mais recorrente, registando-se tigelas de perfil simples e bordo geralmente engrossado (21 NMI; $n^{\circ} 84$ a 89), ou mais aplanado e bem assinalado na área externa (12 NMI; $n .^{\circ}$ 90 a 96). Ambas as morfologias exibem as superfícies bem polidas sendo, em alguns casos, cobertas com engobes ou aguadas esbranquiçadas. Entre as formas fechadas contam-se dois fragmentos que parecem corresponder a jarros (2 NMI; $n .^{\circ} 97$ e 98), um dos quais com asa conservada, e ainda dois recipientes de perfil esférico e bordo reentrante (2 NMI; n. ${ }^{\circ} 99$ e 100). As panelas do Grupo de Fabrico III estão representadas por vários fragmentos (8 NMI; n. ${ }^{\circ} 101$ a 104). Vasos com decoração pintada surgem também com frequência (10 NMI; n. 105 a 110) correspondendo, muito provavelmente, a pithoi, ainda que em alguns casos (n. ${ }^{\circ} 109$ e 110), se pudessem também relacionar com algumas variantes de urnas tipo Cruz del Negro, concretamente com os tipos 5 ou 6 definidos para a necrópole de Medellín, datadas do século VI a.C. (Torres 2008). A este ou a outro tipo de vasos devem também pertencer os vários fragmentos de asas recolhidos, com secções bífidas (três fragmentos), circulares (cinco fragmentos) e ovaladas (um fragmento) (n. ${ }^{\circ} 111$ a 114). Neste conjunto registaram-se ainda dois bordos de forma indeterminada (2 NMI) e fundos de perfil aplanado (oito fragmentos; $n .^{\circ} 115$ a 117) e convexo (11 fragmentos; $n .{ }^{\circ}$ 118 a 120). Uma outra base (n. $\left.{ }^{\circ} 121\right)$ parece corresponder a uma forma fechada, podendo pertencer a um dos jarros anteriormente referidos.

A cerâmica manual permanece escassa no conjunto, com apenas quatro fragmentos (2 NMI), correspondentes a uma tigela de superfícies alisadas (1 NMI; n. $\left.{ }^{\circ} 123\right)$ e a um vaso tipo pote/panela, com superfícies grosseiras e bordo evertido decorado com incisões (1 NMI; n. ${ }^{\circ}$ 124), uma característica frequente no repertório regional desde o Bronze Final (Arruda 1999-2000; Cardoso 2004). Os restantes fragmentos correspondem a fundos de perfil aplanado e superfícies alisadas.

Neste conjunto da fase 3 recuperou-se ainda um fragmento cerâmico de forma circular, claramente afeiçoado, feito a partir de uma peça com pintura vermelha na área externa (1 NMI; n. ${ }^{\circ}$ 122). Trata-se de artefactos relativamente frequentes na Idade do Ferro, podendo corresponder a fichas de jogo ou a elementos utilizados para cálculo, não sendo, contudo de excluir outras possibilidades (Vives-Ferrándiz et al. 2015). Cabe registar que, no contexto regional, uma peça semelhante foi recolhida em níveis coetâneos na Alcáçova de Santarém (Sousa e Arruda 2018). 


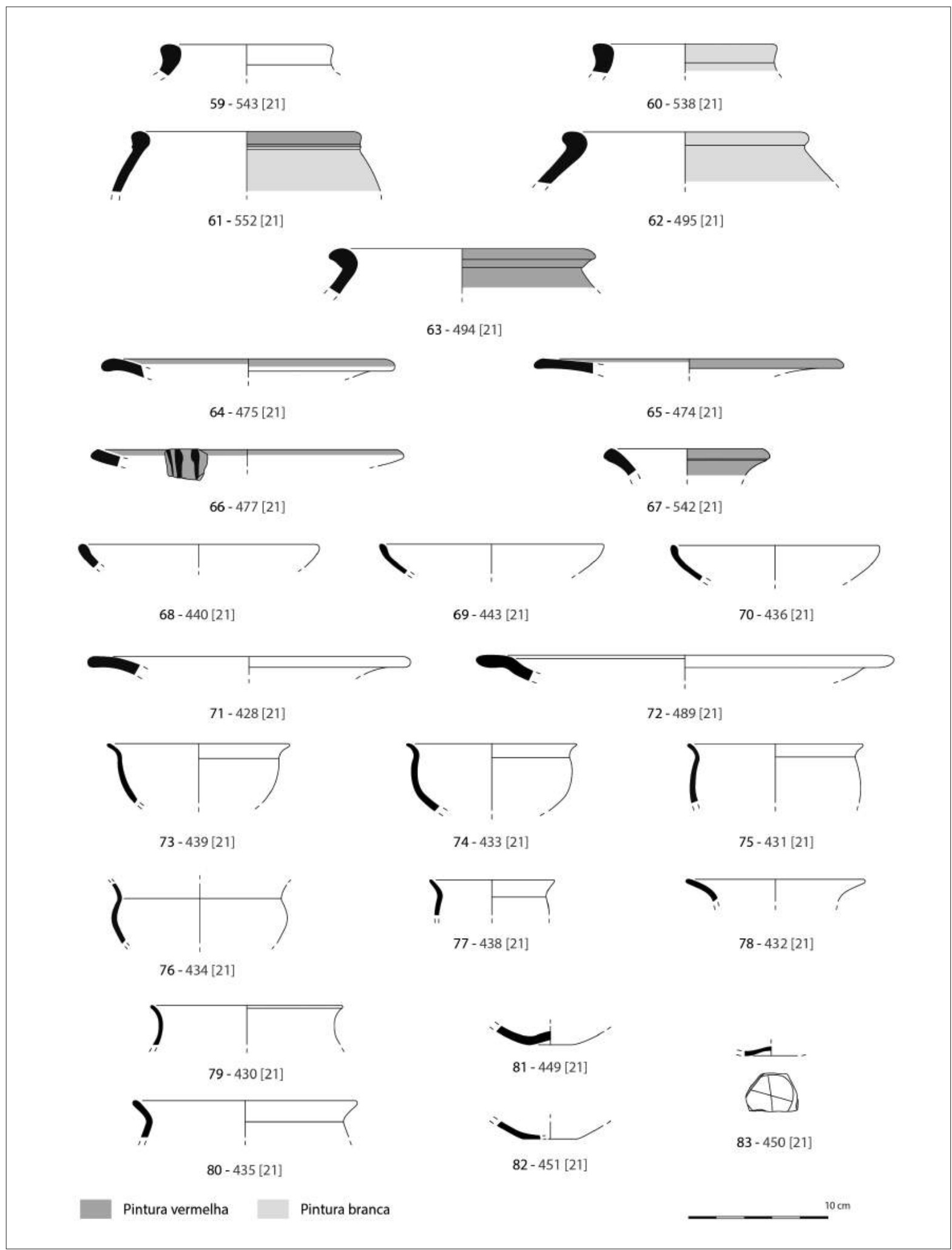

Fig. 14: Materiais da fase 3. 
A presença fenícia em Lisboa: novos vestígios descobertos no alto da colina do Castelo de São Jorge

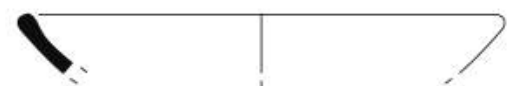

$84-519[21]$

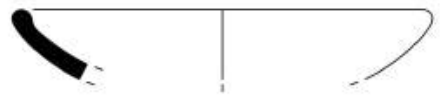

$86-514[21]$

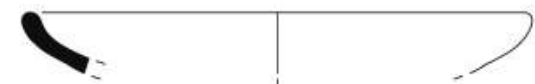

$88-518[21]$

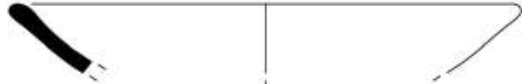

$89-512[21]$

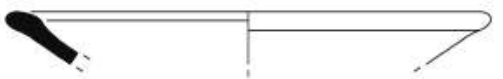

$91-511[21]$

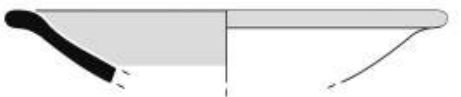

$93-504[21]$

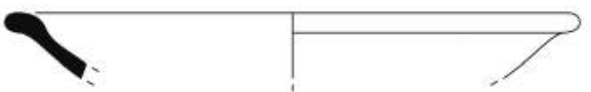

$95-510[21]$

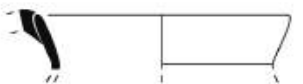

$97-556[21]$

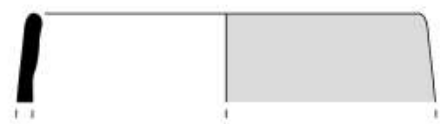

$99-536[21]$

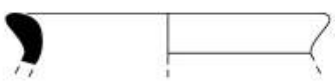

$101-453$ [21]

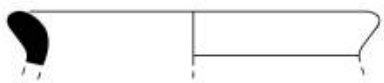

$103-459[21]$

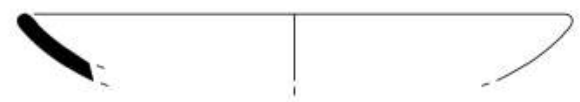

$85-513$ [21]

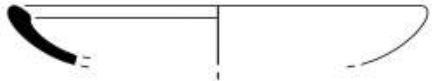

$87-518$ [21]

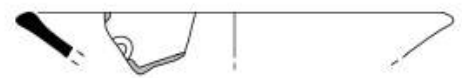

$90-515$ [21]

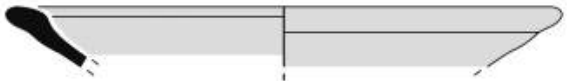

$92-505$ [21]

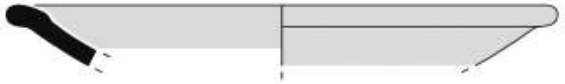

94 - 502 [21]

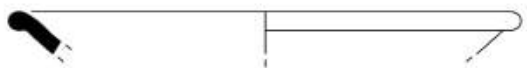

$96-533[21]$

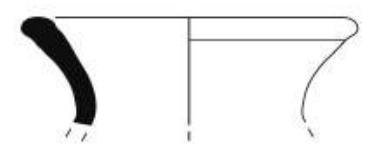

$98-554$ [21]

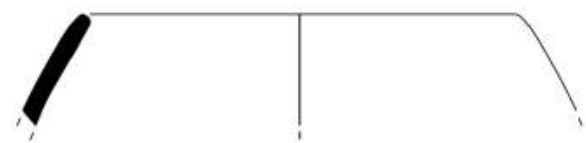

$100-493$ [21]

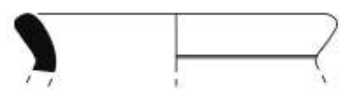

$102-457[21]$

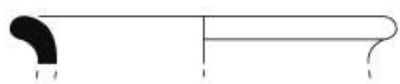

$104-441[21]$

Pintura branca

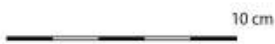

Fig. 15: Materiais da fase 3. 


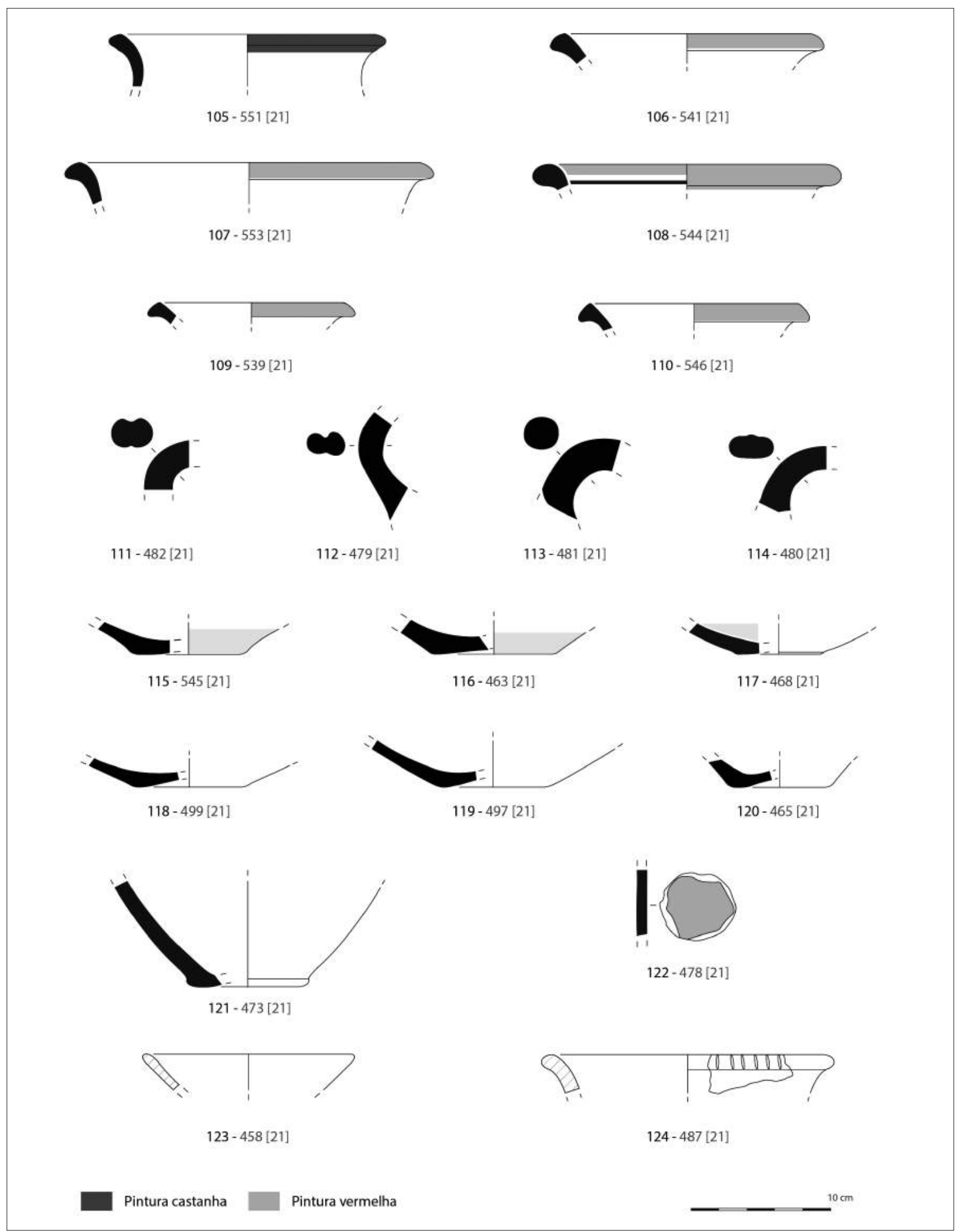

Fig. 16: Materiais da fase 3. 
Os materiais recolhidos nesta terceira fase poderão integrar-se cronologicamente num momento centrado no século VI a.C., provavelmente, durante a sua primeira metade. Com efeito, a presença de morfologias anfóricas que exibem perfis mais evertidos, que parecem de certa forma anunciar o aparecimento do tipo 3 do estuário do Tejo, que surge plenamente configurado a partir de meados desta última centúria (Sousa e Pimenta 2014), assim como a emergência de formas de cerâmica cinzenta com perfis mais evoluídos, são elementos que suportam esta datação.

\section{FASE 4}

A quarta fase de ocupação da Idade do Ferro é, sem dúvida, a mais bem representada no âmbito do repertório artefactual, contando com 411 fragmentos (310 NMI), que se dividem em ânforas (23 fragmentos: $15 \mathrm{NMI}$ ), cerâmica de engobe vermelho (28 fragmentos: $19 \mathrm{NMI}$ ), cerâmica cinzenta ( 147 fragmentos: $114 \mathrm{NMI}$ ), cerâmica comum e pintada (204 fragmentos: $155 \mathrm{NMI}$ ), cerâmica manual (seis fragmentos: $4 \mathrm{NMI}$ ), uma possível importação do Mediterrâneo oriental (um fragmento: $1 \mathrm{NMI}$ ) e outros objectos (dois fragmentos: $2 \mathrm{NMI}$ (fig. 17 a 22).

Entre os contentores anfóricos, cabe, antes de mais, assinalar a recolha de um fragmento pertencente a uma ânfora importada da área meridional do território peninsular, muito provavelmente também da costa de Málaga (1 NMI - n. ${ }^{\circ}$ 125), integrando-se no tipo 10.1.2.1 definido por Ramon (1995). Com efeito, as características da sua pasta, de tonalidade esbranquiçada, e com inclusões de minerais negros alongados, distinguem-se com facilidade das produções locais. Estas últimas continuam a ser predominantes no conjunto, mas neste momento verifica-se uma importante alteração no quadro morfológico. As ânforas do tipo 1 do estuário do Tejo estão ainda presentes no conjunto (4 NMI; n. 126 a 129), mas são agora suplantadas pelo tipo 3 (5 NMI; n. ${ }^{\circ} 134$ a 138), que se caracterizam pelo seu bordo claramente evertido e engrossado exteriormente, formando um lábio bem assinalado. Quatro fragmentos (4 NMI; n. 130 a 133) poderiam enquadrar-se em formas de transição entre o tipo 1 e o tipo 3. Dentro das ânforas do tipo 1, cabe ainda destacar a presença de um bordo emoldurado (n. $\left.{ }^{\circ} 129\right)$, uma característica já documentada no quadro destas produções locais, nomeadamente em Eira da Alorna e no Alto dos Cacos (Sousa e Pimenta, 2014). Neste conjunto integra-se ainda um bordo (1 NMI) que não permitiu uma classificação específica, um fundo de perfil côncavo (n. ${ }^{\circ}$ 140) e de oito fragmentos de asa de secção circular, quatro dos quais cobertos com engobe branco (n. $\left.{ }^{\circ} 139\right)$.

Também na cerâmica de engobe vermelho se verificam importantes alterações no quadro do elenco morfológico. É o caso da introdução das tigelas de perfil hemisférico, com bordo de secção arredondada (2 NMI; n. ${ }^{\circ} 141$ e 142), semelhantes ao tipo C4 de Rufete (1988-1989), e de pratos com carena acentuada, a partir da qual se desenvolve uma parede horizontal (1 NMI; $n .^{\circ} 149$ ), sendo esta uma forma que encontra correspondência no tipo 3Ba estabelecido para a Rua dos Correeiros (Sousa 2014: 122). Os pratos de perfil mais simples e bordo aplanado continuam, contudo, a ser a forma mais recorrente (13 NMI; n. 143 a 148). Cabe ainda destacar a presença de um vaso de diâmetro algo reduzido, de bordo simples e evertido (1 NMI; n. $\left.{ }^{\circ} 150\right)$. Recolheram-se também alguns fragmentos de fundo, com bases aplanadas (n. ${ }^{\circ} 153$ e 154), que correspondem, muito provavelmente, a pratos, e um outro, de pé aparentemente mais alto (n. $\left.{ }^{\circ} 152\right)$, que poderá pertencer à base do prato tipo $3 \mathrm{Ba}$, elemento que permitiria a classificação desta forma como pátera. Deve ainda destacar-se que num destes exemplares (n. ${ }^{\circ}$ 153), a superfície externa encontra-se recoberta de uma aguada esbranquiçada, uma característica relativamente comum no âmbito destas produções locais (Sousa 2017). Por último, registou-se também um fragmento da parte inferior de um recipiente de pequenas dimensões, podendo corresponder a algum tipo de unguentário (1 NMI - $\mathrm{n}$. 151), e um bordo que não permitiu uma classificação específica (1 NMI).

As produções cinzentas são abundantes, englobando tigelas de perfil hemisférico (50 NMI; n. ${ }^{\circ}$ 156, 160, 161, $162,163,166)$, ou de paredes mais oblíquas (16 NMI; $n$. ${ }^{\circ}$ $155,157,158,159,164,165,167)$, sendo o bordo de secção sub-circular e geralmente engrossado, e verificando-se, em dois casos (n..$^{\circ} 155$ e 163) um ligeiro perfil carenado. Um outro fragmento (1 NMI; n. $\left.{ }^{\circ} 168\right)$ poderá corresponder quer a um prato quer a um vaso fechado de bordo evertido. Curiosa é também a presença de uma carena acentuada, que poderá pertencer a um prato do tipo $2 \mathrm{Ab}$ da Rua dos Correeiros (n. ${ }^{\circ}$ 169), situação também documentada no conjunto da Sé de Lisboa (Arruda et al. 2000). Taças ou vasos de pequena dimensão surgem também no conjunto (33 NMI), podendo apresentar bordos evertidos de tendência oblíqua (n. ${ }^{\circ} 170$ a 172), sendo outros menos inclinados (n. ${ }^{\circ} 173$ e 174). As formas mais completas apresentam ou um corpo de perfil carenado 


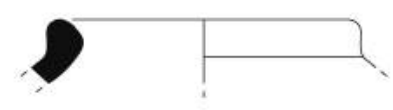

$125-377[18]$

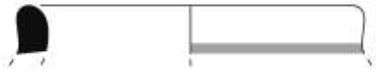

$127-72[18]$

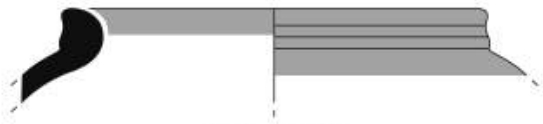

$129-363$ [18]

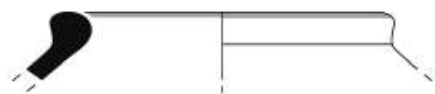

$131-692[8=18]$

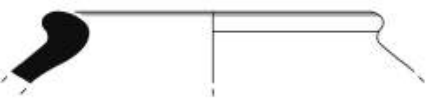

$133-218$ [18]

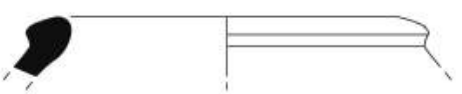

$135-67[18]$

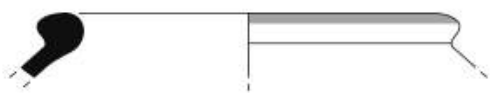

$137-215[18]$

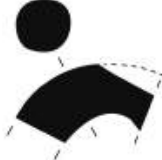

$139-186[18]$

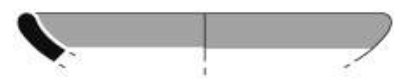

$141-87[18]$

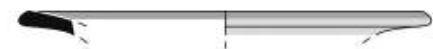

$143-273[18]$

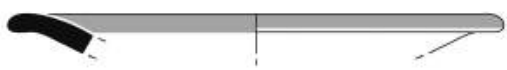

$145-265$ [18]

Pintura castanha acinzentada

Pintura vermelha

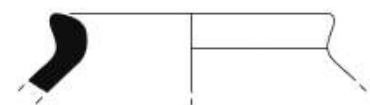

$126-217[18]$

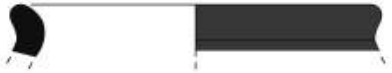

$128-81[18]$

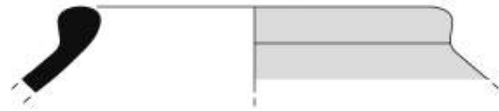

$130-216[18]$

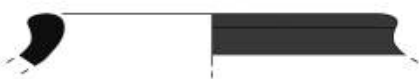

$132-40[18]$

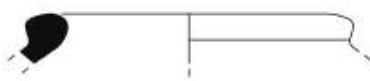

$134-112[18]$

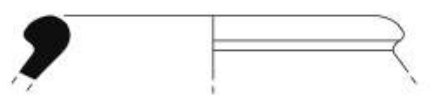

$136-78[18]$

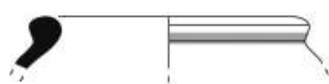

138- 378 [18]

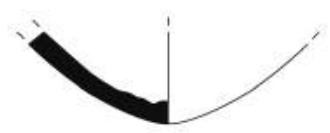

$140-364[18]$
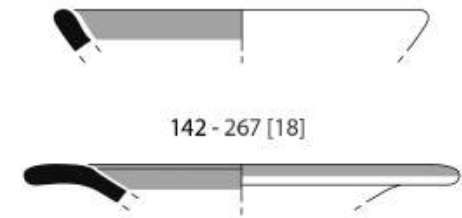

$144-89[18]$

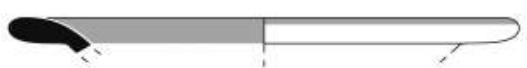

$146-98[18]$

Pintura branca $10 \mathrm{~cm}$

Fig. 17: Materiais da fase 4. 
A Presença fenícia em Lisboa: novos vestígios descobertos no alto da colina do Castelo de São Jorge

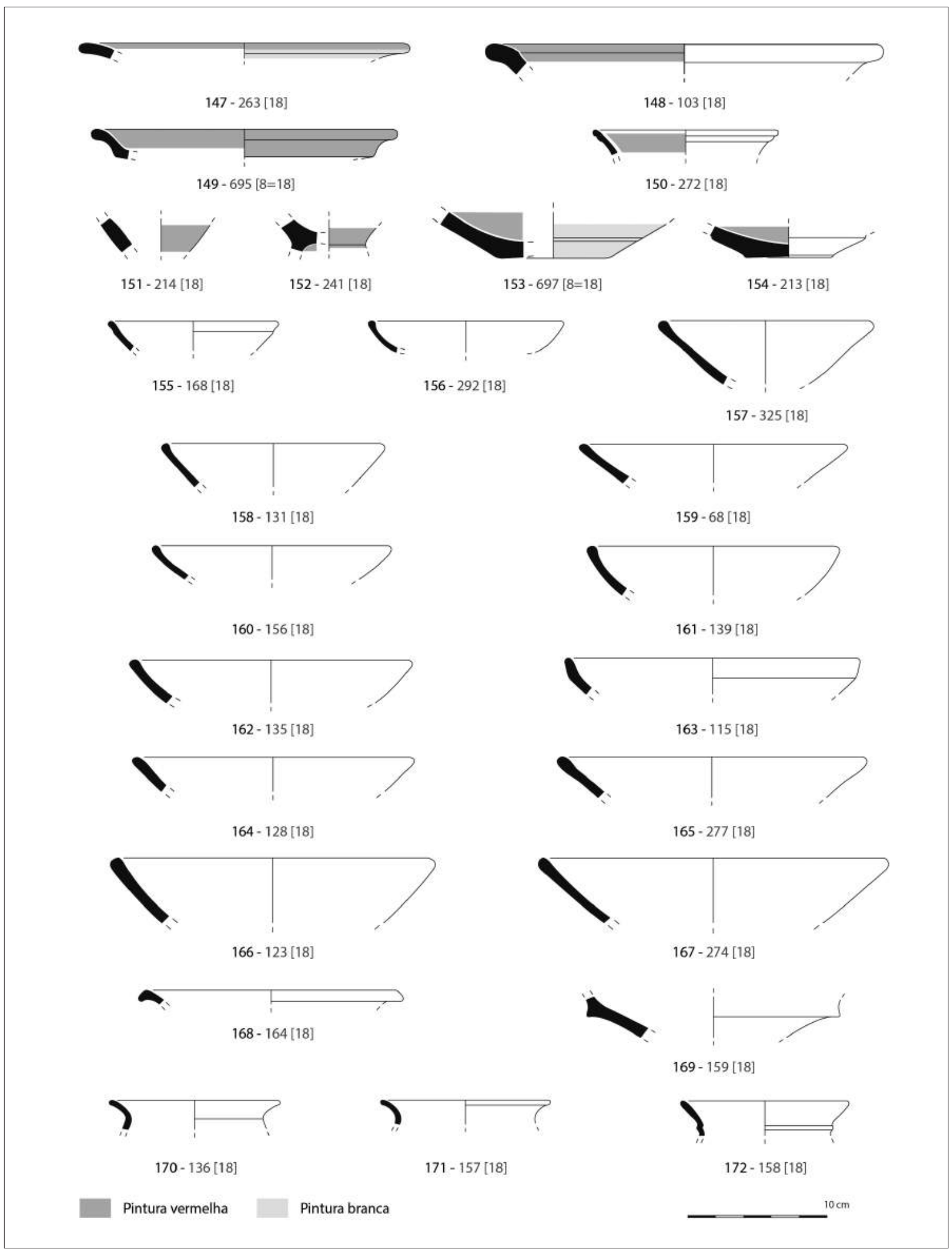

Fig. 18: Materiais da fase 4. 
Elisa de Sousa, SANDra GuERra

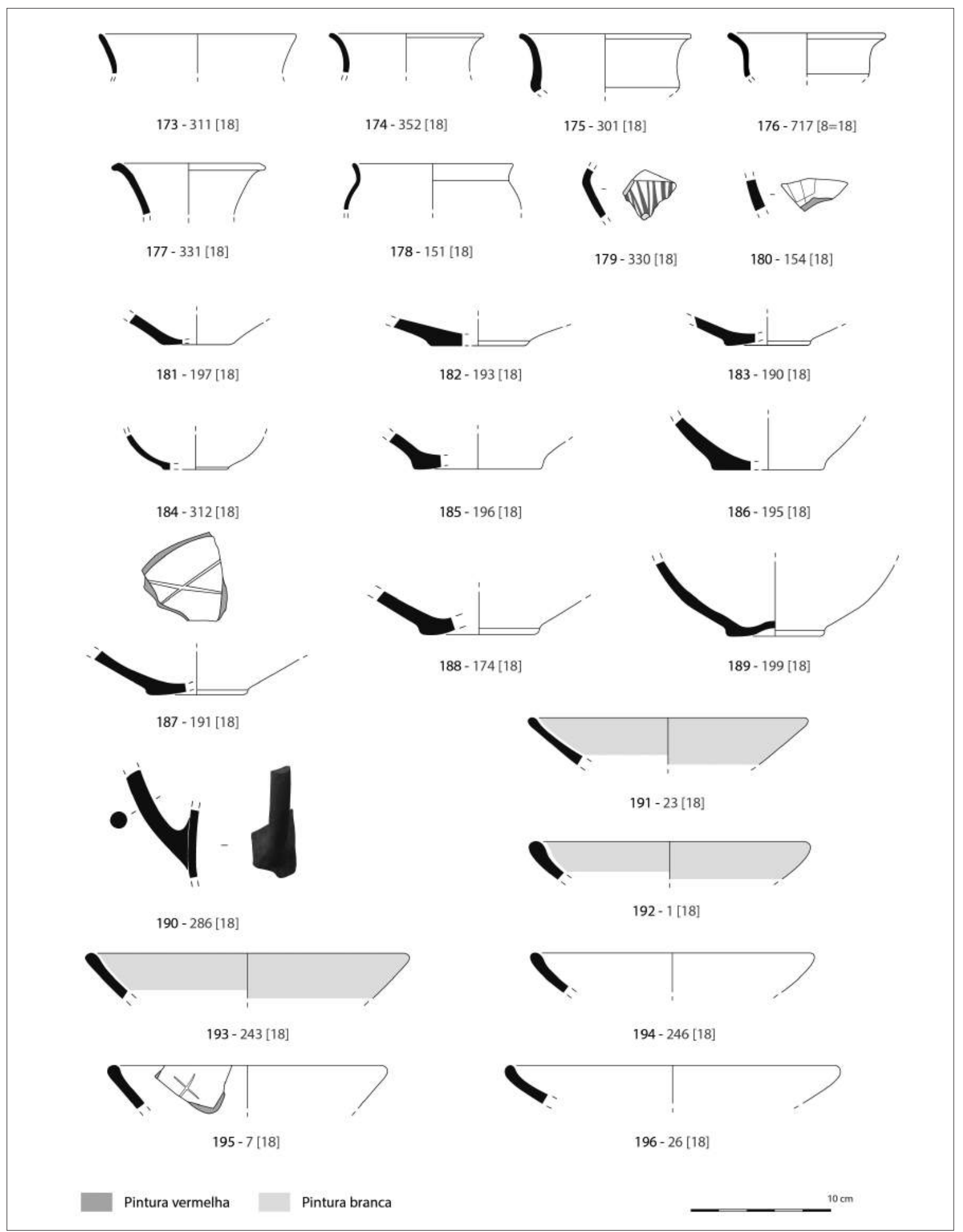

Fig. 19: Materiais da fase 4. 
(n. 175 a 176) ou globular (n. ${ }^{\circ} 178$ ), sendo estas morfologias recorrentes no conjunto publicado da Sé de Lisboa (tipo 3 e 6: Arruda et al. 2000). Deve ainda referir-se a presença de um vaso de colo alto e evertido, que poderá corresponder a um jarro (1 NMI; $\left.n .^{\circ} 177\right)$. Deste grupo de cerâmicas cinzentas fazem parte também treze fragmentos de bordo inclassificáveis (13 NMI), duas paredes decoradas na área externa com motivos brunidos, formando traços verticais e oblíquos (n. $\left.{ }^{\circ} 179\right)$ e com uma marca incisa (n. ${ }^{\circ}$ 180), uma asa de secção circular e vários fragmentos de fundo de perfil aplanado (11 fragmentos; n. ${ }^{\circ} 181,182$, $185,186,187)$ ou convexo (18 fragmentos; n. ${ }^{\circ} 183,188$, 189), por vezes com pé destacado, tendo um deles uma marca incisa em forma de X na área interna (n. $\left.{ }^{\circ} 187\right)$. Destacam-se, contudo, duas peças de corpo mais globular, podendo uma delas corresponder a uma taça (n. $\left.{ }^{\circ} 184\right)$, sendo a restante seguramente de uma forma fechada (n. ${ }^{\circ}$ 189), porventura do jarro anteriormente referido.

A cerâmica comum e pintada desta quarta fase é muito abundante, estando representada por tigelas de perfil hemisférico (43 NMI) ou de paredes oblíquas (14 NMI), com bordo de secção sub-circular e geralmente engrossado (n. 191 a 198), apresentando, com frequência, engobes ou aguadas esbranquiçadas ou, na sua ausência, um cuidado polimento das suas superfícies. Cabe registar a presença de uma marca incisa, em forma de $\mathrm{X}$, na área interna de uma destas peças ( $\mathrm{n}^{\circ}$ 195). Dois casos (2 NMI) apresentam características mais atípicas, um deles com bordo claramente reentrante (n. $\left.{ }^{\circ} 199\right)$ e um outro com uma canelura na área superior interna (n. $\left.{ }^{\circ} 200\right)$, podendo corresponder a algum tipo de tampas. Também frequente neste conjunto é a presença de outras morfologias de tigelas que, contudo, se distinguem pelos seus bordos diferenciados e, por vezes, de perfil aplanado (11 NMI; n. 201 a 207). Uma outra peça merece destaque, correspondendo à parte inferior de um recipiente que se desenvolveria com paredes horizontais na área superior e com um pé talvez desenvolvido na inferior (1 NMI; $n$. 209), apresentando muitas semelhanças com as páteras do tipo 4Aa da Rua dos Correeiros (Sousa 2014: 160). Os pratos estão menos bem representados (4 NMI; n. ${ }^{\circ} 210$ a 212), tendo bordos aplanados e revestimentos brancos nas suas superfícies. Um outro conjunto de recipientes de maior diâmetro e bordos mais engrossados poderão corresponder a algum tipo de bacia ou alguidar (3 NMI; $n$. $^{\circ}$ 213 e 214), sendo de destacar que também estas formas recebem revestimentos esbranquiçados nas suas superfícies. As formas fechadas estão também bem representadas nesta fase. As fabricadas com argilas menos depuradas (Grupo de Fabrico III) são frequentes, correspondendo a panelas (20 NMI; n. 216 a 221). Tal como ocorre nas restantes fases, estes fragmentos exibem quase sempre as superfícies queimadas, evidenciando a sua exposição constante ao fogo. Cabe registar, contudo, a presença de uma peça deste mesmo fabrico com um diâmetro reduzido (1 NMI; n. ${ }^{\circ} 222$ ), mais apto para a contenção de líquidos, mas que apresenta as mesmas evidências das anteriores. Trata-se de um fenómeno que não é inédito em Lisboa, considerando que na Rua dos Correeiros surgem uma série de vasos de diâmetro reduzido fabricados com estas mesmas pastas (tipo 11Ab: Sousa 2014), e que sugerem que, no quadro das tradições culinárias do estuário do Tejo, a elaboração de algum tipo de bebida quente terá sido uma realidade durante, pelo menos, os meados do $1^{\circ}$ milénio a.C. Neste grupo incluem-se também dois fragmentos de fundo que corresponderão, com grande probabilidade, às bases das panelas anteriormente referidas ( $\mathrm{n}$. $^{\circ}$ 223 e 224). Vasos de tipo pithos com decoração pintada continuam a estar bem representados no conjunto. Trata-se de morfologias mais evolucionadas, com diâmetros variáveis e colos aparentemente mais curvilíneos (42 NMI; n. 225 a 238). Seis fundos de perfil côncavo e cinco fragmentos de asas de secção bífida, por vezes cobertas com engobe branco, devem também pertencer a esta forma ( . $\left.^{\circ} 240\right)$. Um outro fragmento (1 NMI; n. ${ }^{\circ} 215$ ) corresponde a uma outra morfologia de vasos de armazenamento, apresentando um diâmetro menos amplo e um bordo de perfil simples. Um outro bordo poderá ainda corresponder a uma urna tipo Cruz del Negro (1 NMI; $n$. 239). A este conjunto somam-se ainda doze fragmentos de bordo inclassificáveis (12 NMI), fundos de perfil aplanado (sete fragmentos; n. ${ }^{\circ} 243$ e 245) e convexo (13 fragmentos; n. ${ }^{\circ}$ 242, 244 e 246), 14 de asas de secção circular, uma de secção ovalada e, por último, uma pega perfurada, coberta com engobe branco na área externa (n. $\left.{ }^{\circ} 241\right)$.

A cerâmica manual continua a ser escassa, contando-se apenas um fragmento de tigela (1 NMI; n. ${ }^{\circ} 247$ ), um recipiente que poderá corresponder a algum tipo de prato, de superfícies alisadas e com incisões sobre o bordo (1 NMI; n. ${ }^{\circ}$ 248), uma taça de superfícies polidas e de perfil carenado, com pintura vermelha em ambas as superfícies (1 NMI; n. . 249), e um vaso de diâmetro reduzido e bordo ligeiramente evertido, de superfícies alisadas (1 NMI; n. ${ }^{\circ} 250$ ), e, por último, dois fundos aplanados, de superfícies alisadas (n. $\left.{ }^{\circ} 251\right)$ ou rugosas. 


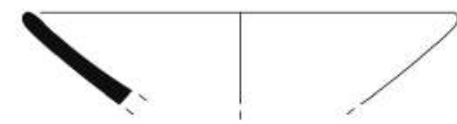

$197-21[18]$

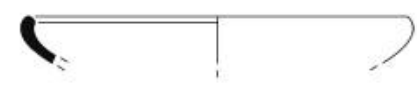

$199-8[18]$

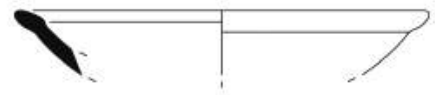

$201-376[18]$

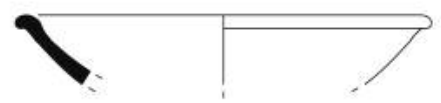

$203-17[18]$

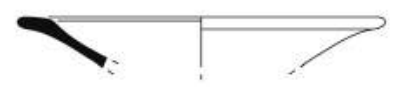

$205-261[18]$

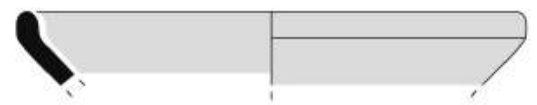

$198-245[18]$

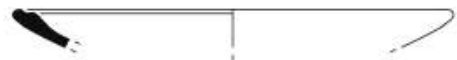

$200-260[18]$

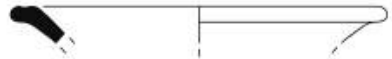

$202-118[18]$

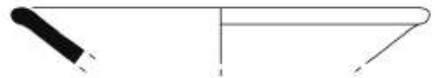

$204-14[18]$

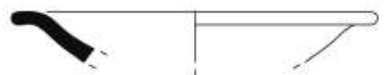

$206-320[18]$

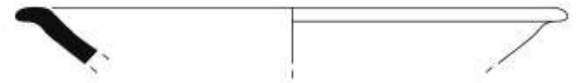

$207-46[18]$

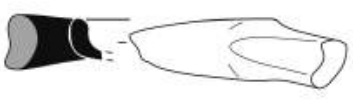

$208-49[18]$

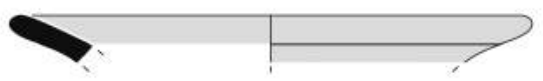

$210-66[18]$

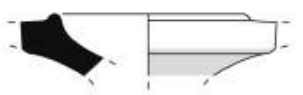

$209-242[18]$

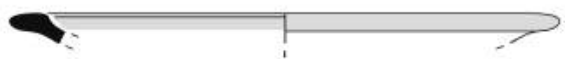

$211-373[18]$

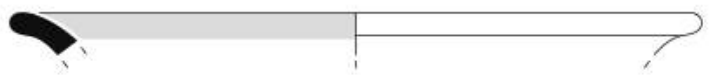

$212-88[18]$

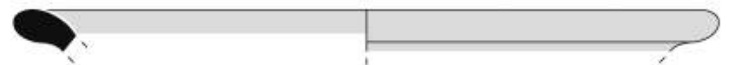

$213-2[18]$

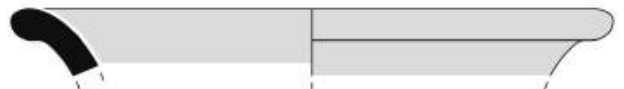

214 - 239 [18]

Pintura branca

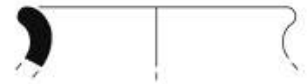

$215-240[18]$

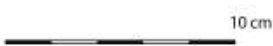

Fig. 20: Materiais da fase 4. 


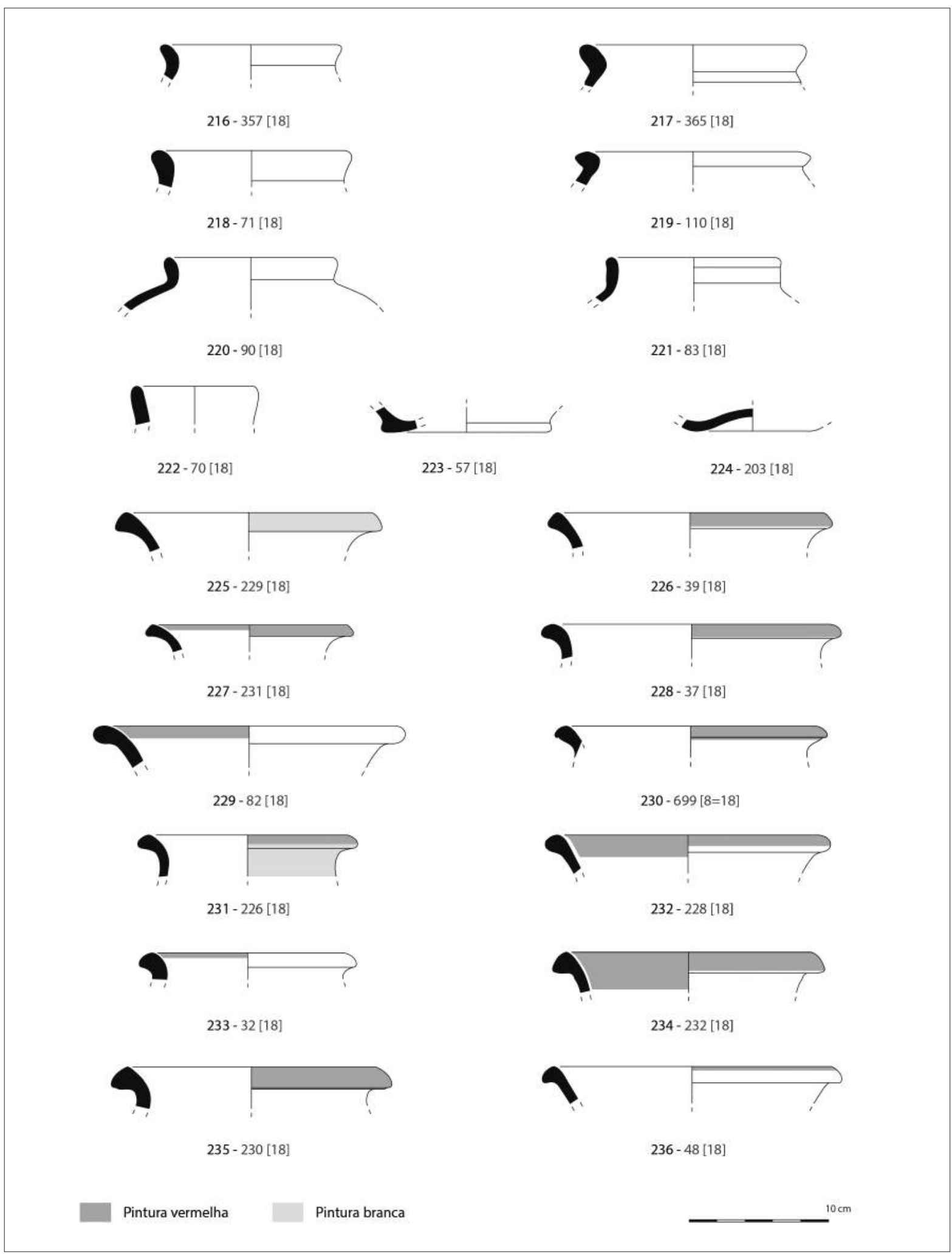

Fig. 21: Materiais da fase 4. 
Elisa de Sousa, Sandra Guerra

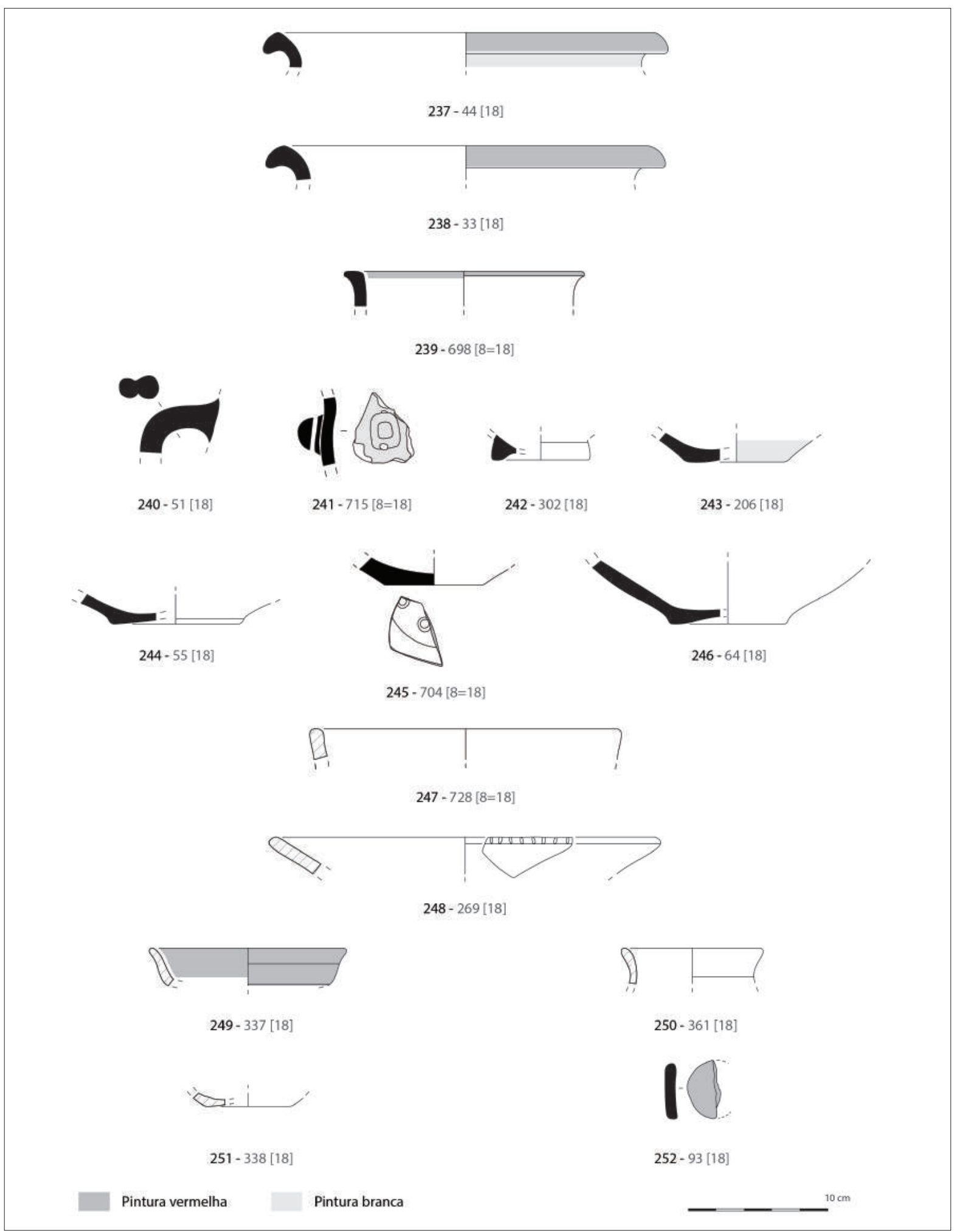

Fig. 22: Materiais da fase 4. 
A peça mais particular recolhida no conjunto desta quarta fase corresponde a um pequeno fragmento de asa e parede (n. $\left.{ }^{\circ} 190\right)$. As características da sua pasta, de tons alaranjados e muito bem depurada, indicam uma possível origem exógena, diferenciando-se também dos fabricos que conhecemos no Sul da Península Ibérica. Poderá tratar-se de uma forma fechada, coberta com uma pintura vermelha na superfície externa, que poderia pertencer a uma olpe ou a uma oinochoe fabricada na área oriental do Mediterrâneo. Contudo, as escassas dimensões do fragmento obrigam a ter cautela acrescida nesta associação, sendo, contudo, importante referir que importações gregas datáveis desta mesma fase estão documentadas na outra margem do Tejo, na Quinta do Almaraz (Barros et al. 1993; Cardoso 2004; Arruda 2005). Por outro lado, não podemos excluir categoricamente a possibilidade de se tratar de uma produção peninsular, mais uma vez de algum tipo de oinochoe coberta com engobe vermelho, situação que só poderá ser clarificada com a realização de futuras análises arqueométricas.

Por último, deve referir-se a presença de dois artefactos cerâmicos (2 NMI) que correspondem a placas afeiçoadas, feitas a partir de fragmentos cobertos com engobe vermelho (1 NMI; $n .^{\circ} 252$ ), semelhantes ao detectado na fase anterior, e a um possível elemento de coroplastia (1 NMI; n. ${ }^{\circ} 208$ ) encontrando-se, infelizmente, mal conservado, não sendo possível esboçar qualquer leitura.

Este conjunto recuperado na quarta fase de ocupação sidérica é, sem dúvida, o mais representativo, denotando alterações significativas no repertório artefactual face às fases precedentes. Os elementos aqui recuperados sugerem uma cronologia centrada na segunda metade do século VI a.C., apresentando vários paralelos com o elenco morfológico recolhido na Sé de Lisboa, datado deste mesmo período (Arruda 1999-2000), não sendo, contudo, impossível que se possa estender até aos inícios da centúria seguinte. A presença de uma ânfora importada do tipo 10.1.2.1 de Ramon (1995), de ânforas claramente integráveis no tipo 3 do estuário do Tejo (Sousa e Pimenta 2014), a introdução de tigelas e pratos de engobe vermelho semelhantes aos tipos C4 de Rufete (1988-1989) e 3Ba da Rua dos Correeiros (Sousa 2014), e dos pequenos potes de corpo globular ou carenado do tipo 3 e 6 da Sé de Lisboa (Arruda et al. 2000), são elementos que corroboram esta cronologia. Contudo, destaca-se também a presença de formas que irão surgir, em Lisboa, plenamente configuradas durante o século $\mathrm{V}$, como é o caso das páteras de cerâmica comum do tipo 4A da Rua dos Correeiros, e de vasos abertos de maiores dimensões de tipo bacia/alguidar, assim como dos pequenos potes de cerâmica cinzenta com colos mais desenvolvidos, que irão culminar nas formas 3A e 3B definidas no sítio da Baixa Pombalina (Sousa 2014).

\section{FASE 5}

A última fase identificada que se associa à ocupação pré-romana proporcionou 46 fragmentos (37 NMI), que correspondem a ânforas (dois fragmentos: $2 \mathrm{NMI}$ ), cerâmica de engobe vermelho (dois fragmentos: 2 NMI), cerâmica cinzenta (15 fragmentos: $13 \mathrm{NMI}$ ), cerâmica comum e pintada (24 fragmentos: $17 \mathrm{NMI}$ ), cerâmica manual (dois fragmentos: 2 NMI) e a uma peça de bronze (um fragmento: $1 \mathrm{NMI}$ ) (fig. 23 e 24).

Os dois únicos fragmentos de ânforas desta fase são integráveis no tipo 1 ( $1 \mathrm{NMI}$; n. $\left.{ }^{\circ} 254\right)$ e no tipo 4 (1 NMI; n. ${ }^{\circ}$ 253) do estuário do Tejo (Sousa e Pimenta 2014), sendo de referir que este último corresponde a uma morfologia que só aparece no registo artefactual da região a partir do século V a.C. (Sousa 2014; Sousa e Pimenta 2014).

A cerâmica de engobe vermelho é escassa, com apenas duas peças. A primeira (1 NMI; $\left.n .^{\circ} 255\right)$ parece corresponder a um pequeno vaso do tipo $6 \mathrm{Bb}$ da Rua dos Correeiros (Sousa 2014: 125-126). A segunda (1 NMI; n. ${ }^{\circ} 256$ ), uma base de pé alto e perfil anelar, exibe características que parecem surgir no repertório desta categoria a partir de meados do $1^{\circ}$ milénio a.C., podendo estar associada a influências da cerâmica grega (Sousa 2014: 127).

A cerâmica cinzenta continua a estar bem representada no conjunto, sendo a forma mais recorrente a tigela de perfil hemisférico (6 NMI; $n .^{\circ} 257$ a 259 ) ou de paredes mais rectas e oblíquas ( $1 \mathrm{NMI}$; . $^{\circ} 260$ ), de bordos geralmente engrossados, que correspondem, respectivamente, aos tipos $1 \mathrm{Aa}$ e $1 \mathrm{Ab}$ da Rua dos Correeiros (Sousa 2014). Um outro fragmento destaca-se por exibir um bordo diferenciado e lábio pendente, podendo enquadrar-se no tipo $1 \mathrm{Ac}\left(1 \mathrm{NMI}\right.$;.$\left.^{\circ} 261\right)$. Entre os vasos de pequena dimensão identificou-se o tipo $3 \mathrm{Ba}(2$ NMI; n. ${ }^{\circ}$ 262) e 4Aa (1 NMI; n. ${ }^{\circ} 263$ ). Alguns fragmentos de colo mais desenvolvido poderão corresponder a jarros do tipo 5Aa (2 NMI; n. ${ }^{\circ} 264$ ). Por último, resta referir a recolha de uma pequena base de perfil convexo (n. $\left.{ }^{\circ} 265\right)$. 
Elisa de Sousa, Sandra Guerra

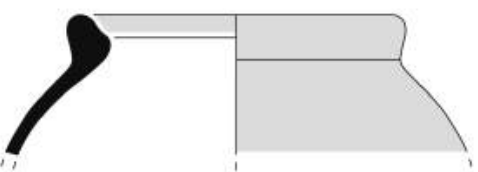

$253-410$ [19]

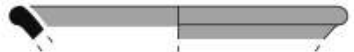

$255-399[15]$

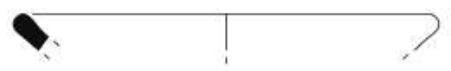

$257-384[15]$

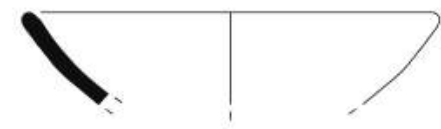

$259-418$ [19]

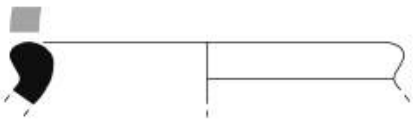

254 - 413 [19]

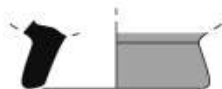

$256-395[15]$

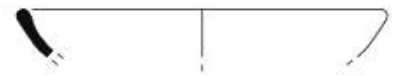

$258-419$ [19]

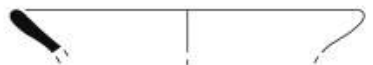

$260-420$ [19]

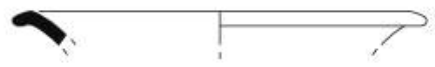

$261-386$ [15]

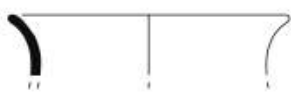

$262-421[19]$

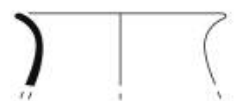

$264-382[15]$

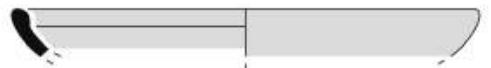

$266-405$ [19]

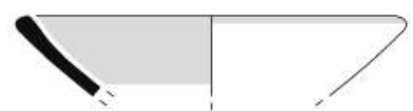

$268-393[15]$

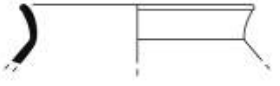

$263-383[15]$

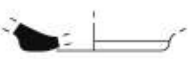

$265-424$ [19]

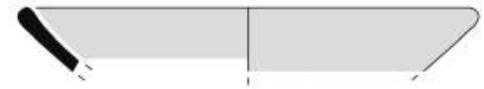

$267-391[15]$

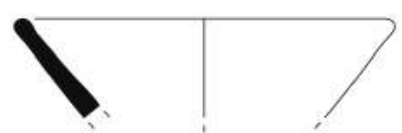

$269-402[19]$

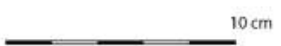

Fig. 23: Materiais da fase 5. 
A PRESEnÇa fenícia Em Lisboa: novos vestígios descobertos no alto da colina do Castelo de São Jorge

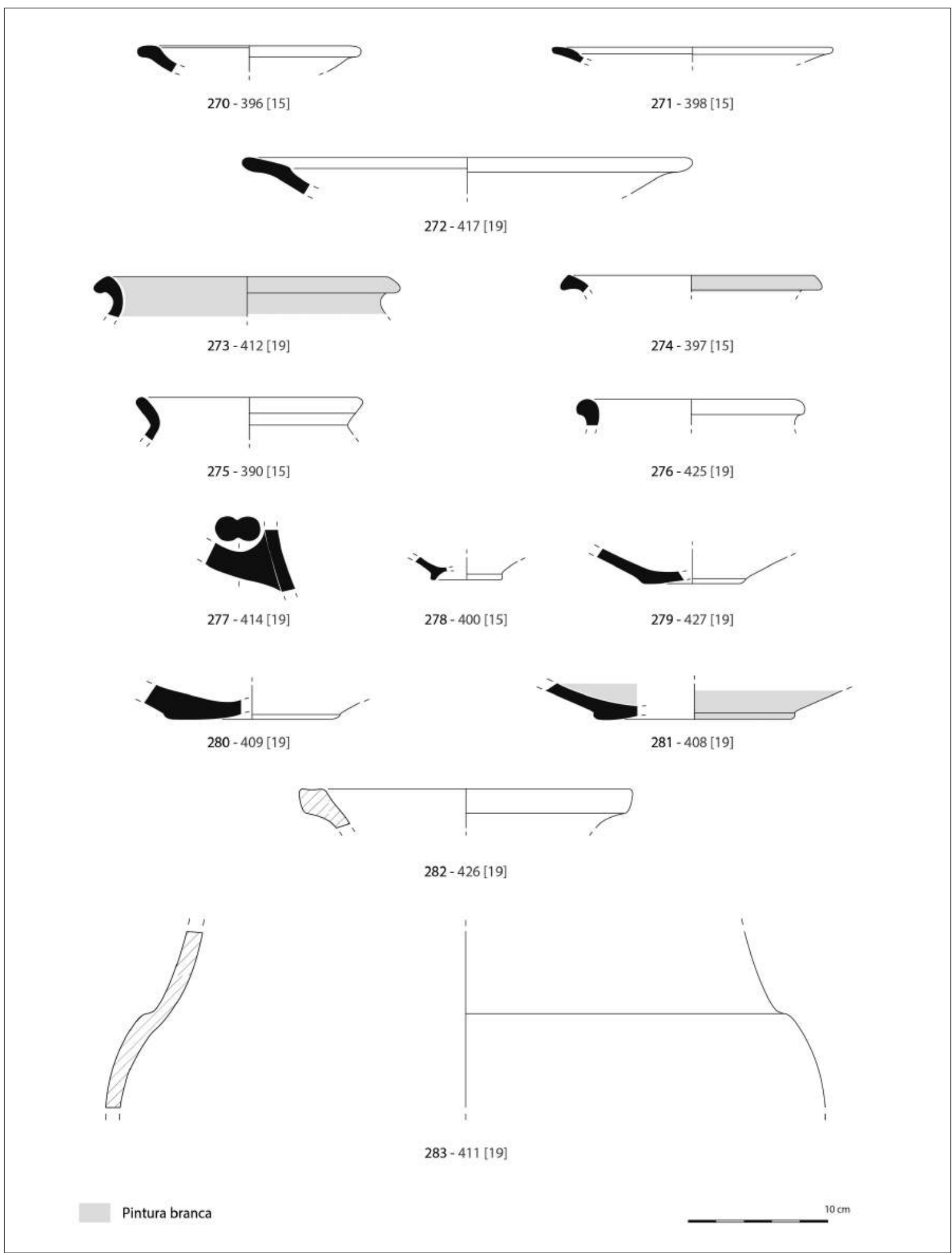

Fig. 24: Materiais da fase 5. 
Entre a cerâmica comum e pintada, a forma mais bem representada é a tigela de perfil hemisférico (7 NMI; $n$. 266 a 268) ou de paredes oblíquas (1 NMI; n. ${ }^{\circ} 269$ ), com bordos geralmente engrossados, que correspondem, respectivamente, aos tipos $1 \mathrm{Aa}$ e $1 \mathrm{Ac}$ da Rua dos Correeiros (Sousa 2014). Entre as formas abertas conta-se ainda uma taça do tipo $2 \mathrm{Ca}$ (1 NMI; n. ${ }^{\circ} 250$ ) e pratos de bordo aplanado (3 NMI; $n$. $^{\circ} 271$ e 272). Tal como se verifica nas fases anteriores, estes recipientes estão recobertos com engobes ou aguadas esbranquiçadas, ou então apresentam as superfícies bem polidas. Entre as formas fechadas contam-se alguns vasos de bordo evertido que parecem evoluir dos pithoi das fases precedentes, enquadrando-se nos tipos 10Ba (1 NMI; n. $\left.{ }^{\circ} 274\right)$ e 10Bb (1 NMI; n. ${ }^{\circ} 273$ ) da Rua dos Correeiros (Sousa 2014). As panelas do tipo 10A (2 NMI) estão também presentes no conjunto, apresentando bordos simples ( . $^{\circ} 275$ ) ou ligeiramente engrossados (n. ${ }^{\circ} 276$ ), tendo as mesmas características de fabrico anteriormente indicadas (Grupo III). Neste conjunto surge ainda um bordo não classificável (1 NMI), uma asa de secção bífida (n. ${ }^{\circ}$ 277) e fundos de perfil convexo (n. 278 a 281).

A cerâmica manual permanece escassa no conjunto, com apenas um bordo de perfil sub-trapezoidal e zona superior aplanada (1 NMI; n. ${ }^{\circ}$ 282), com superfícies grosseiras, e uma parede carenada, de superfícies alisadas, que recorda, de certa forma, o perfil dos vasos $\grave{a}$ chardon (1 NMI; n. ${ }^{\circ} 283$ ).

Por último, deve referir-se que, no conjunto desta última fase, foi recolhido um artefacto metálico, correspondente a uma pequena faixa larga e pouco espessa, provavelmente de bronze (1 NMI), de difícil classificação.

Esta última fase de ocupação será seguramente datável no século V a.C. Apesar de este conjunto da fase 5 ser escasso em termos quantitativos, verifica-se já a presença, no grupo dos contentores anfóricos, do tipo 4 do estuário do Tejo, uma morfologia que surge no repertório artefactual regional apenas a partir deste período. $\mathrm{O}$ tipo 1 continua, contudo, a ser fabricado, situação que se verifica também em outros locais do estuário (Sousa 2014; Sousa e Pimenta 2014). O conjunto de cerâmica de engobe vermelho é limitado, sendo de destacar a presença de formas bem documentadas na Rua dos Correeiros (tipo 6Bb e pés altos de perfil anelar). No grupo da cerâmica cinzenta, nota-se também um notável paralelismo com as formas documentadas na Baixa Pombalina (tipos $1 \mathrm{Aa}, 1 \mathrm{Ab}, 1 \mathrm{Ac}, 3 \mathrm{Ba}, 4 \mathrm{Aa}$ ), assim como a presença de jarros (tipo 5Aa) que se encontram bem documentados na zona do estuário em contextos de idêntica cronologia (Sousa 2014).

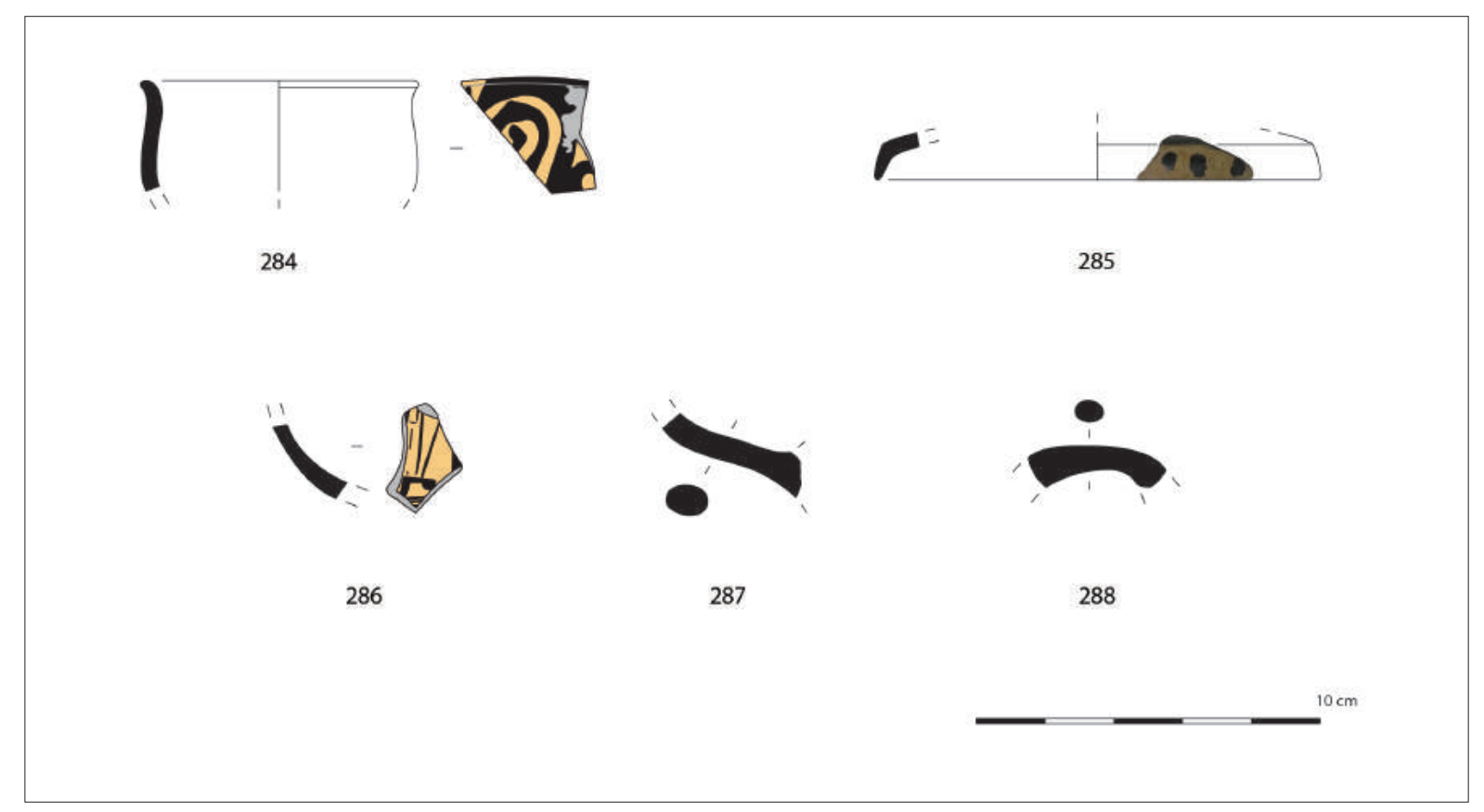

Fig. 25: Fragmentos de cerâmica grega recolhidos durante as escavações. 
Seguramente relacionados com esta ocupação de meados do $1^{\circ}$ milénio a.C. estão cinco fragmentos de cerâmica grega recuperados durante a intervenção (fig. 25) mas que, infelizmente, foram recolhidos em contextos secundários. Destes, três são seguramente vasos áticos de figuras vermelhas, correspondendo a um skyphos (n. ${ }^{\circ}$ 284), uma tampa, provavelmente de uma lekane ( $\mathrm{n} .^{\circ}$ 285), e um fragmento de parede de uma kilyx (n. ${ }^{\circ} 286$ ). Os restantes dois fragmentos correspondem a asas pertencentes a esta mesma forma (n. ${ }^{\circ} 287$ e 288). Trata-se de formas já conhecidas na cidade e também no próprio estuário do Tejo (Arruda e Sousa no prelo), com a excepção da tampa, identificada agora pela primeira vez, sendo enquadráveis, cronologicamente, entre a segunda metade do século V e inícios do século IV a.C.

\section{CONSIDERAÇÕES FINAIS}

A importância do conjunto artefactual recuperado nesta intervenção reside, como já foi anteriormente referido, no facto de esta ser a primeira sequência estratigráfica bem caracterizada do ponto de vista quantitativo da ocupação orientalizante da Colina do Castelo de São Jorge, em Lisboa. A sua análise e interpretação enfrenta, contudo, algumas limitações e condicionantes que apenas poderão ser ultrapassadas com estudos e publicações futuras que incidam sobre este período cronológico.

Um dos aspectos mais problemáticos centra-se na correcta definição de fases cronológicas específicas. Como já foi referido anteriormente, o espólio orientalizante da antiga Lisboa resulta, na sua esmagadora maioria, de produções realizadas em âmbito local, situação que dificulta a extrapolação directa de indicadores cronológicos estabelecidos para outras regiões. Apesar de serem viáveis alguns paralelismos no quadro da evolução da cultura material com conjuntos exumados na costa meridional da Península Ibérica, deveremos ter sempre em consideração que os oleiros que se estabeleceram no vale do Tejo poderão ter desenvolvido outras tendências morfológicas nas diversas categorias cerâmicas por eles fabricadas, logo desde os primeiros momentos da ocupação da Idade do Ferro, materializando-se numa evolução de certa forma independente da respectiva cultura material. A própria distância geográfica que separa a Península de Lisboa dos centros fenícios da costa andaluza poderá ter condicionado um certo isolamento das comunidades que habitaram no centro da fachada atlântica face a novas tendências evolutivas meridionais do repertório cerâmico que, ainda assim, chegam a atingir esta área, sendo adoptadas e incorporadas no conjunto artefactual, como se verifica, por exemplo nos elencos morfológicos da cerâmica de engobe vermelho e na cerâmica comum (Sousa 2014; 2016a; 2017).

Este cenário, aliado à relativa escassez de materiais importados, gera, por conseguinte, certas dificuldades no estabelecimento de fases cronológicas específicas, em particular para os momentos mais antigos da ocupação da Idade do Ferro. Como tal, o faseamento cronológico que apresentamos para os distintos momentos é apenas uma proposta de trabalho, que terá de ser confirmada e afinada em trabalhos futuros.

Por outro lado, deve também reconhecer-se que o elenco morfológico recuperado nesta intervenção não representa toda a diversidade formal do repertório da fase orientalizante de Lisboa. Com efeito, as diferentes fases identificadas não têm a mesma expressão quantitativa, encontrando-se alguns momentos cronológicos mais bem representados que outros. Os dados que foram aqui apresentados têm de ser futuramente integrados com outros elementos recuperados ao longo da vertente meridional da Colina do Castelo (Arruda 1999-2000; Fernandes et al. 2013; Calado et al. 2013a, 2013b; Filipe et al. 2014; Pimenta et al. 2005, 2014a, 2014b, 2015; Sousa 2016a, 2017; Sousa e Pinto 2016; Sousa et al. 2016), uma tarefa que só será possível através da clara associação dos elementos da cultura material a contextos estratigráficos específicos. Esta situação é particularmente relevante no que diz respeito à cerâmica de engobe vermelho, cuja diversidade formal durante a $1^{\mathrm{a}}$ metade do $1^{\mathrm{o}}$ milénio a.C. é bem mais ampla do que a registada neste trabalho, sobretudo nas fases mais antigas da ocupação (Sousa 2016a; 2017).

Uma análise geral dos dados recolhidos durante a escavação deste sector do Largo de Santa Cruz do Castelo (n. ${ }^{\circ}$ ) demonstra um perfil de consumo bastante constante ao longo das distintas fases, sendo apenas de destacar um aumento progressivo do peso das cerâmicas cinzentas à medida que nos aproximamos dos meados do $1^{\circ}$ milénio (ver fig. 10). Este aumento parece gerar-se em detrimento de uma certa diminuição do peso das cerâmicas comuns ou pintadas, podendo esta relação associar-se ao maior sucesso das produções cinzentas no âmbito do serviço de mesa, uma situação que já se verificou em outras áreas de Lisboa (Sousa 2016a). Por outro lado, a distribuição das diferentes categorias, em particular a escassa 
representatividade dos contentores anfóricos e a recorrência de vasos aparentemente destinados à confecção de alimentos, são indicadores que parecem apontar para uma ocupação de carácter essencialmente doméstico, proposta suportada também pelas significativas quantidades de fauna recolhidas, que se encontram actualmente em estudo.

Um outro aspecto que parece importante salientar é a escassa representatividade das produções manuais ao longo de toda a diacronia, que nunca chegam a atingir os $10 \%$ da totalidade do conjunto, mesmo durante as fases mais antigas desta ocupação, datáveis em torno ao século VII a.C. Esta situação contrasta com a registada naquele que é, até ao momento, o contexto mais antigo associável à ocupação sidérica da Colina do Castelo, identificado na Rua de São Mamede ao Caldas e datado dos finais do século VIII / inícios do século VII a.C., onde a cerâmica manual, que reproduz ainda as tradições regionais do Bronze Final, representa $61 \%$ do espólio recuperado, estando associada, entre outros artefactos, a vários pratos e taças cobertas de engobe vermelho e a uma urna tipo Cruz del Negro (Pimenta et al. 2014b). Se esta disparidade se relaciona com uma maior antiguidade deste último contexto, com áreas de matriz cultural mais indígena integradas no seio deste antigo núcleo de povoamento, ou com questões de amostragem, é uma problemática que não podemos ainda esclarecer, sendo para tal essencial a recuperação e publicação de dados mais precisos e representativos dos momentos iniciais da ocupação da Idade do Ferro na área.

Não restam, contudo, dúvidas que o cenário documentado no Largo de Santa Cruz do Castelo (n. ${ }^{\circ} 7$ ) revela, logo desde os momentos iniciais da ocupação, a incorporação massiva de cerâmicas feitas a torno, que são já fabricadas no contexto local. Esta evidência sugere que os grupos humanos que se instalaram no topo da colina do Castelo de São Jorge detinham já hábitos culinários e de consumo de alimentos plenamente integráveis na chamada matriz cultural orientalizante e que não são, por sua vez, muito distintos dos detectados em vários horizontes coloniais do Sul peninsular, como por exemplo o Cerro del Villar (Aubet et al. 1999) ou Cádis (da fase III do Teatro Cómico - Torres et al. 2014). Com efeito, as grandes diferenças assinaláveis residem na escassez, em Lisboa, de importações do Mediterrâneo Central e Oriental, e de outras formas mais específicas, como é o caso de lucernas, oil bottles e trípodes, podendo estas últimas relacionar-se eminentemente com problemas de amostragem e de representatividade dos contextos arqueológicos publicados. Por outro lado, a especificidade de algumas das morfologias documentadas em Lisboa devem-se, seguramente, ao desenvolvimento das suas próprias produções logo desde o momento inicial da chegada de populações fenícias-ocidentais a este território, e que evoluíram, em certos aspectos, em linhas diferenciadas mas, de certa forma, paralelas ao que se regista no Sul da Península Ibérica. Não obstante, o elemento mais importante a reter é que estas especificidades são observáveis no âmbito da produção de categorias claramente orientalizantes (ânforas, cerâmica de engobe vermelho, cerâmica cinzenta e cerâmica comum e pintada), que dominam o repertório artefactual da antiga Lisboa desde, pelo menos, o século VII a.C.

Com efeito, estes dados parecem suportar a proposta de que o núcleo de povoamento fundado na colina do Castelo de São Jorge, em finais do século VIII ou inícios do século VII a.C., está directamente relacionado com a chegada e fixação de grupos fenício-ocidentais, podendo corresponder a um ambiente de cariz colonial instalado no estuário do Tejo (Sousa 2015, 2016a, 2016b). As características da cultura material exumada nas escavações do Largo de Santa Cruz do Castelo (n. ${ }^{\circ}$ 7) permitem, assim, uma contextualização mais sólida de outros elementos significativos que têm sido identificados, durante os últimos anos, em vários pontos da elevação, como é o caso das duas inscrições em caracteres e língua fenícia (Arruda 2013; Zamora 2014; Neto et al. 2016), e dos inúmeros artefactos cerâmicos de matriz orientalizante (Arruda 1999-2000; Fernandes et al. 2013; Calado et al. 2013a, 2013b; Filipe et al. 2014; Pimenta et al. 2005, 2014a, 2014b, 2015; Sousa e Pinto 2016).

\section{BIBLIOGRAFIA}

ARRUDA, A. M. (1999-2000): Los Fenicios en Portugal. Fenicios y mundo indígena en el centro y sur de Portugal (siglos VIII-VI a.C.), Barcelona.

ARRUDA, A. M. (2005): O $1^{\circ}$ milénio a.n.e. no Centro e no Sul de Portugal: leituras possíveis no início de um novo século, $O$ Arqueólogo Português IV-3, 9-156.

ARRUDA, A. M. (2013): Do que falamos quando falamos de Tartesso, Tarteso. El emporio del metal (J. Campos, J. Alvar, eds.), Huelva, 211-222.

ARRUDA, A. M.; FREITAS , V.; VALLEJO SÁNCHEZ, J. (2000): As cerâmicas cinzentas da Sé de Lisboa, Revista Portuguesa de Arqueologia 3 (2), 25-59. 
ARRUDA, A. M.; FREITAS, V.; OLIVEIRA, C. (2007): Os Fenícios e a urbanização no Extremo Ocidente: o caso de Castro Marim, Las ciudades fenicio-púnicas en el Mediterráneo Occidental (J. L. López Castro, ed.), Almería, 459-482.

ARRUDA, A. M.; SOUSA, E. (no prelo): Greek pottery in the Tagus estuary.

AUBET, M. E.; CARMONA, P.; CURIÀ, E.; DELGADO, A.; FERNÁNDEZ CANTOS, A.; PÁRRAGA, M. (1999): Cerro del Villar. I. El asentamiento fenício en la desembocadura del rio Guadalhorce y su interacción com el hinterland, Sevilha.

BARROS, L.; CARDOSO, J. L.; SABROSA, A. (1993): Fenícios na margem sul do Tejo. Economia e integração cultural do povoado de Almaraz - Almada, Estudos Orientais 4, 143-181.

CALADO, M.; ALMEIDA, L.; LEITÃO, V.; LEITÃO, M. (2013): Cronologias absolutas para a I Idade do Ferro em Olisipo - o exemplo de uma ocupação em ambiente cársico na actual Rua da Judearia em Alfama, Cira Arqueologia 2, 118-132.

CALADO, M.; PIMENTA, J.; FERNANDES, L.; FILIPE, V. (2013b): Conjuntos cerámicos da Idade do Ferro do Teatro Romano de Lisboa: as cerâmicas de engobe vermelho, $\mathrm{Ar}$ queologia em Portugal. 150 anos (J. Arnaud; A. Martins; C. Neves, eds.), Lisboa, 641-649.

CARDOSO, J. L. (2004): A Baixa Estremadura dos Finais do IV milénio a.C. até à chegada dos romanos: um ensaio de história regional, Oeiras.

FERNANDES, L.; PIMENTA, J.; CALADO, M.; FILIPE, V. (2013): Ocupação sidérica na área envolvente do teatro romano de Lisboa: o Pátio do Aljube, Revista Portuguesa de Arqueologia 16, 167-185.

FILIPE, V.; CALADO, M.; LEITÃO, M. (2014): Evidências orientalizantes na área urbana de Lisboa. O caso dos edifícios na envolvente da Mãe de Água do Chafariz d 'El Rei, Fenícios e Púnicos, por terra e mar. Actas do VI Congresso Internacional de Estudos Fenícios e Púnicos (A. M. Arruda, ed.), Lisboa, vol. 2, 736-747.

LORRIO, A. J. (2008): Cerámica gris, La necrópolis de Medellín II. Estudio de los hallazgos (M. Almagro-Gorbea, dir.), Madrid, vol. 2, 673-723.

MANCEBO, J. (1991-1992): La cerámica de barniz o engobe rojo de Montemolín (Sevilla), Zephyrus XLIV-XLV, 269-299.

NETO, N.; REBELO, P.; RIBEIRO, R.; ROCHA, M.; ZAMORA LÓPEZ, J. (2016): Uma inscrição lapidar fenícia em Lisboa, Revista Portuguesa de Arqueologia 19, 123-128.

PIMENTA, J.; CALADO, M.; LEITÃO, M. (2005): Novos dados sobre a ocupação pré-romana da cidade de Lisboa. As ânforas da sondagem n.o 2 da Rua de São João da Praça, Revista Portuguesa de Arqueologia 8 (2), 313-334.
PIMENTA, J.; CALADO, M.; LEITÃO, M. (2014a): Novos dados sobre a ocupação pré-romana da cidade de Lisboa. A intervenção da Rua de São João da Praça, Fenícios e Púnicos, por terra e mar. Actas do VI Congresso Internacional de Estudos Fenícios e Púnicos (A. M. Arruda, ed.), Lisboa, vol. 2, 724-735.

PIMENTA, J.; SILVA, R.; CALADO, M. (2014b): Sobre a ocupação pré-romana de Olisipo. A intervenção arqueológica urbana da Rua de São Mamede ao Caldas n. ${ }^{\circ} 15$, Fenícios e Púnicos, por terra e mar. Actas do VI Congresso Internacional de Estudos Fenícios e Púnicos (A. M. Arruda, ed.), Lisboa, vol. 2, 712-723.

PIMENTA, J.; SOUSA, E.; AMARO, C. (2015): Sobre as mais antigas ocupações da Casa dos Bicos, Lisboa: da Olisipo pré-romana aos primeiros contactos com o mundo italico, Revista Portuguesa de Arqueologia 18, 161-180.

RAMON, J. (1995): Las Ánforas Fenicio-Púnicas del Mediterráneo Central y Occidental, Barcelona.

RAMON, J.; SÁEZ ESPLIGARES, A.; SÁEZ ROMERO, A.; MUÑOZ, A. (2007): El taller alfarero tardoarcaico de Camposoto (San Fernando, Cádiz), Sevilha.

ROUILLARD,P.; GAILLEDRAT,E.; SALAF.(2007): L'établissement protohistorique de La Fonteta (fin VIIIe - fin VIe siècle av. J.C.), Madrid.

RUFETE, P. (1988-89): Las cerámicas con engobe rojo de Huelva, Huelva Arqueológica XXI-3, 10-40.

RUFETE, P. (2002): El Final de Tartessos y el período turdetano en Huelva, Huelva.

RUIZ, D. (1993): Los fenícios de época arcaica -siglos VIII/VII a.C.- en la bahía de Cádiz. Estado de la cuestión, Estudos Orientais IV, 23-72.

RUIZ, D.; PÉREZ PÉREZ, C. (1995): El poblado fenício del Castillo de Doña Blanca (El Puerto de Santa María, Cádiz), Cádiz.

SOUSA, E. (2014): A ocupação pré-romana da foz do Estuário do Tejo, Lisboa.

SOUSA, E. (2015): The Iron Age occupation of Lisbon, Madrider Mitteilungen 56, 109-138.

SOUSA, E. (2016a): A Idade do Ferro em Lisboa: uma primeira aproximação a um faseamento cronológico e à evolução da cultura material, CUPAUAM 42, 167-185. DOI: https://dx.doi.org/10.15366/cupauam2016.42.006

SOUSA, E. (2016b): The Tagus estuary (Portugal) during the 8th - 5th BC: stage of transformation and construction of identity, Transformations and Crisis in the Mediterranean. 'Identity' and Interculturality in the Levant and Phoenician West during the 8th-5th Centuries BCE. (G. Garbati, T. Pedrazzi, eds.), Roma, 279-300.

SOUSA, E. (2017): A cerâmica de engobe vermelho de Lisboa, $I$ Encontro de Arqueologia de Lisboa, Lisboa, 212-221.

SOUSA, E.; PIMENTA, J. (2014): A produção de ânforas no Estuário do Tejo durante a Idade do Ferro, As Produções Cerâmicas 
de Imitação na Hispânia (R. Morais; A. Fernández; M. J. Sousa, eds.), Porto, vol. 1, 303- 316.

SOUSA, E.; PINTO, M. (2016): A ocupação da Idade do Ferro na colina do Castelo de Sao Jorge (Lisboa, Portugal): novos dados das escavações realizadas na Rua do Recolhimento/Beco do Leão, Apontamentos de Arqueologia e Património 11, 59-67.

SOUSA, E.; SARRAZOLA, A.; SIMÃO, I. (2016): Lisboa pré-romana: contributos das intervenções arqueológicas na Rua da Madalena, Apontamentos de Arqueologia e Património 11, 69-79.

SOUSA, E.; ARRUDA, A. M. (2018): A I Idade do Ferro na Alcáçova de Santarém (Portugal): os resultados da campanha de 2001, Onuba 6, 57-95.

TORRES, M. (2008): Urnas de tipo Cruz del Negro, La necropolis de Medellín II. Estudio de los hallazgos (M. Almagro-Gorbea, dir.), Madrid, vol. 2, 631-654.
TORRES, M.; LÓPEZ ROSENDO, E.; GENER, J. M.; NAVARRO, M. A.; PAJUELO. J. M. (2014): El material cerámico de los contexto fenicios del "Teatro Cómico" de Cádiz: un análisis preliminar, Los Fenicios en la Bahía de Cádiz. Nuevas investigaciones (M. Botto, ed.), Pisa-Roma, 51-82.

VIVES-FERRÁNDIZ, J.; BONET, H.; CARRIÓN MARCO, Y.; FERRER GARCÍA, C. (2015): Ofrendas para una entrada: un depósito ritual en la Puerta Oeste de la Bastida de les Alcusses (Moixent, Valencia), TP 72 (2), 282-303.

ZAMORA, J. A. (2014): Palabras fluidas en el extremo Occidente. Sobre un nuevo grafito fenicio, hallado en la desembocadura del Tajo, que recoge un posible topónimo local, Homenaje a Ricardo Olmos. Per speculum in aenigmate (P. Bádenas, P. Cabrera, M. Moreno,A. Ruiz, C. Sánchez, T. Tortosa, eds.), Madrid, 306-314. 